\title{
PARQUE NACIONAL DA SERRA DA CANASTRA: ASPECTOS FÍSICOS E SOCIOECONÔMICOS
}

\author{
SERRA DA CANASTRA NATIONAL PARK: \\ PHYSICAL AND SOCIO-ECONOMIC ASPECTS

\section{PARQUE NACIONAL SERRA DA CANASTRA: ASPECTOS FÍSICOS E SOCIOECONÓMICOS}

\author{
Cassiano Gustavo Messias \\ Observação da Terra (OBT). Instituto Nacional de Pesquisas Espaciais (INPE). \\ E-mail: cassiano.messias@inpe.br
}

\section{Marcos César Ferreira}

Departamento de Geografia/Instituto de Geociências/Universidade Estadual de Campinas (UNICAMP).

E-mail: macferre@ige.unicamp.br

\section{Resumo}

O Parque Nacional da Serra da Canastra está localizado a sudoeste do estado de Minas Gerais, no Brasil. Situada no domínio morfoclimático do cerrado, esta unidade de conservação foi criada, em 1972, com o intuito de conservar as belezas cênicas desta região, a diversidade de fauna e flora e as nascentes dos rios São Francisco e Araguari. Este artigo tem como objetivo realizar a caracterização física e socioeconômica desse parque e de sua zona de amortecimento. Seus resultados trazem uma síntese e discussão de material bibliográfico e cartográfico preexistentes, abordando aspectos geológicos, pedológicos, geomorfológicos, climáticos, hidrográficos e vegetacionais. Foi gerado o mapa de uso do solo do ano de 2018 , a partir de técnicas de classificação orientada a objetos e imagens do satélite Landsat 8, sensor OLI. As caracterizações econômica e populacional foram fundamentadas em mapas temáticos, gráficos e tabelas, que foram gerados por meio de dados obtidos por pesquisas realizadas pelo Instituto Brasileiro de Geografia e Estatística (IBGE).

Palavras-chave: Parque Nacional da Serra da Canastra/MG, unidades de conservação, caracterização física, caracterização econômica, caracterização populacional.

\section{Abstract}

The Serra da Canastra National Park is located in the Southwest of Minas Gerais state, in Brazil. Placed on the Brazilian savanna (cerrado) biome, this conservation unit was created in 1972, with the purpose of preserving the scenic beauty of the region, the diversity of fauna and flora, and the springs of the São Francisco and Araguari rivers. This article aimed to present the physical and socio-economic characterization of this park and its buffer zone. The results bring a synthesis and discussion of preexisting bibliographical references and cartographic material, approaching geological, pedological, geomorphological, climatic, 
hydrographic and vegetative aspects. The land use map of the year of 2018 was generated from object-oriented classification technique and Landsat 8 satellite OLI sensor images. The economic and population characterizations were based on thematic maps, graphics and tables, which were generated from data obtained by researches conducted by the Brazilian Institute of Geography and Statistics.

Keywords: Serra da Canastra National Park, parks, physical characterization, economic characterization, population characterization.

\section{Resumen}

El Parque Nacional Serra da Canastra se encuentra en el suroeste del estado de Minas Gerais, en Brasil. Situada en el dominio morfoclimático del cerrado, esta unidad de conservación fue establecida en 1972, con el propósito de conservar las bellezas escénicas de la región, la diversidad de fauna y flora, y las nacientes de los ríos São Francisco y Araguari. Este artículo tiene como objetivo realizar la caracterización física y socioeconómica de este parque y su zona de amortiguamiento. Sus resultados traen una síntesis y discusión de material bibliográfico y cartográfico preexistentes, abordando aspectos geológicos, pedológicos, geomorfológicos, climáticos, hidrográficos y vegetacionales. Se generó el mapa de uso del suelo del año 2018, a partir de técnicas de clasificación orientada a objetos e imágenes del satélite Landsat 8, sensor OLI. Las caracterizaciones económica y poblacional fueron fundamentadas en mapas temáticos, gráficos y tablas, que fueron generados a través de datos obtenidos en investigaciones realizadas por el Instituto Brasileño de Geografía y Estadística.

Palabras clave: Parque Nacional Serra da Canastra, unidades de conservación, caracterización física, caracterización económica, caracterización poblacional.

D D p.71-112, V.15, n.27, mai./ago. 2019. 


\section{Introdução}

Antes da chegada dos europeus à serra da Canastra, esta região era ocupada por grupos indígenas que ali viviam havia milhares de anos. Estes povos tradicionais eram muito ligados ao ambiente natural e passavam sua cultura de geração a geração. Essa região foi palco de disputas sangrentas, a partir da chegada dos exploradores bandeirantes. Em 1675, os índios cataguazes foram dizimados e, apesar de se saber pouco sobre os costumes e modo de vida deste povo, sabe-se que eram bravos e lutaram muito até serem vencidos (BIZERRIL et al., 2008).

A denominação serra da Canastra está associada à passagem dos bandeirantes por esta região, no século XVII, que associaram a serra a um tipo de arca móvel de formato retangular que levavam em suas tropas (MMA, IBAMA, 2005). Contudo, essa região só ganhou importância política e econômica com a abertura de caminhos para as minas goianas, no século XVIII. Neste período, houve a concessão de terras pelo império e incentivos para a atividade agropecuária (BARBOSA, 2007). O interesse nessa região veio também de naturalistas, entre eles o francês Saint-Hilaire, que, em 1819, foi até o local para conhecer a nascente do rio São Francisco (CHAVES et al., 2009).

A maior parte dos municípios dessa região teve origem no período setecentista. Contudo, foi no século XIX que se consolidaram os núcleos de povoamento (MMA, IBAMA, 2005). O crescimento municipal esteve associado ao desenvolvimento econômico, que se deu a partir de atividades agropecuárias e do garimpo. A economia e a população se desenvolveram também por meio da fabricação de aguardentes, doces, laticínios e do queijo canastra. Os habitantes que ali se instalaram buscaram preservar suas tradições e costumes, enraizados até os dias atuais (BIZERRIL et al., 2008).

Um importante fato, que viria a mudar por completo essa região, foi a criação do Parque Nacional da Serra da Canastra (PNSC), pelo Decreto $n^{\circ}$ 70.355, de 03 de abril de 1972, que abrangeria 197.787 ha (BRASIL, 1972). A desapropriação das terras para a criação do parque foi um processo conturbado e que acirrou conflitos territoriais (BARBOSA, 2007). Devido a problemas de regularização fundiária e a dificuldades de acesso e fiscalização, excluíram-se do parque as áreas do Chapadão da Babilônia e se estabeleceu, em 1977, que o PNSC seria composto apenas dos 71.525 ha do Chapadão da Canastra (MMA, IBAMA, 2005).

A criação do Parque Nacional da Serra da Canastra veio acompanhada de grande impacto na produção camponesa local. Exemplos disto foram as restrições atribuídas ao manejo tradicional (que incluía, entre outros métodos, a utilização de queimadas para 
a renovação das pastagens no período de inverno), o que levou à queda na produção de queijos. Diante das perdas dos proprietários de terra e das restrições às atividades agropastoris, o turismo surgiu como uma atividade alternativa, contudo, os problemas de infraestrutura dificultam o turismo na região da serra da Canastra. No período das chuvas, muitas estradas se tornam intransitáveis, o que compromete o deslocamento de turistas e também o escoamento da produção (BARBOSA, 2007).

Em 2005, houve a publicação do segundo plano de manejo do PNSC, que se diferencia do anterior principalmente por contemplar a área que consta no decreto de criação do parque. Esse plano faz uma análise estratégica dos objetivos específicos para o manejo, o zoneamento e o planejamento do parque, englobando o Chapadão da Canastra, o Chapadão da Babilônia e também a sua zona de amortecimento (ZA) (MMA, IBAMA, 2005). Nesse momento, surgiram novas tensões e mobilizações na região, especialmente por parte dos camponeses que defendiam sua permanência nos 130.000 ha que ainda não haviam sido regularizados (FERREIRA, 2015).

Em 2007, o Projeto de Lei no $1.448 / 07$ propôs novamente a alteração da área do PNSC, colocando que a transformação de parte desta unidade de conservação (UC) em área de preservação ambiental (APA) permitiria a exploração de quartzito e de diamante no interior do parque (MELLES et al., 2007). Contudo, o rio São Francisco, que nasce na serra da Canastra, é ameaçado pela existência de garimpos clandestinos e de outras pressões sobre a qualidade de suas águas, sendo que a mineração é uma das principais atividades geradoras de impactos no alto São Francisco (CBHSF, 2016). Nesse sentido, a possibilidade de redução da área do PNSC diminuiria, na mesma proporção, a proteção dos recursos ambientais, podendo seriamente afetar a disponibilidade hídrica do rio São Francisco.

O PNSC continua, atualmente, com uma área definida de 197.787 ha, sendo que valores próximos de 86.000 ha são regularizados. A zona regularizada é constituída pelo Chapadão da Canastra e por fragmentos no Chapadão da Babilônia que foram doados, a partir de 2010, para compensação de reserva legal (FERREIRA, 2015). Os proprietários destes fragmentos desocuparam a área, mas o parque ainda não consegue geri-los de forma adequada, por serem "ilhas" desapropriadas em meio a um "mar" de áreas não desapropriadas (MMA et al., 2018).

A relevância do PNSC está associada à preservação da grande diversidade de fauna e flora do cerrado, de sua beleza cênica e da presença de nascentes de importantes rios, como o São Francisco e o Araguari. Contudo, sua preservação está ameaçada por problemas ambientais e atividades conflitantes, tais como: queimadas frequentes, desenvolvimento de

D 
processos erosivos, áreas de mineração e não regularização de extensas áreas. Ainda nos dias presentes, após mais de quarenta anos da criação do parque, existem graves problemas entre a população local e a conservação dessa unidade (MMA, IBAMA, 2005).

Este artigo tem como objetivo caracterizar aspectos físicos e socioeconômicos da área que abrange o PNSC e sua zona de amortecimento. Serão levantados aspectos populacionais e econômicos dos municípios que abrangem esta UC. Na sua caracterização física, serão contemplados aspectos geológicos, pedológicos, geomorfológicos, climáticos e hidrográficos. Será também discutido o uso do solo atual e serão caracterizadas as principais coberturas vegetais.

\section{Localização da área de estudo}

O Parque Nacional da Serra da Canastra está localizado a sudoeste do estado de Minas Gerais, no Brasil. Esta UC está inserida nos municípios de São Roque de Minas, Sacramento, Delfinópolis, São João Batista da Glória, Capitólio e Vargem Bonita. Sua zona de amortecimento, além dos municípios já citados, inclui também Alpinópolis, Cássia, Ibiaci, Passos e Piumhi (Figura 1). A zona regularizada é constituída pelo Chapadão da Canastra e por pequenas manchas no Chapadão da Babilônia, enquanto a zona não regularizada está basicamente associada ao Chapadão da Babilônia.

Figura 1: Mapa de localização da área de estudo em escalas estadual, municipal e local.
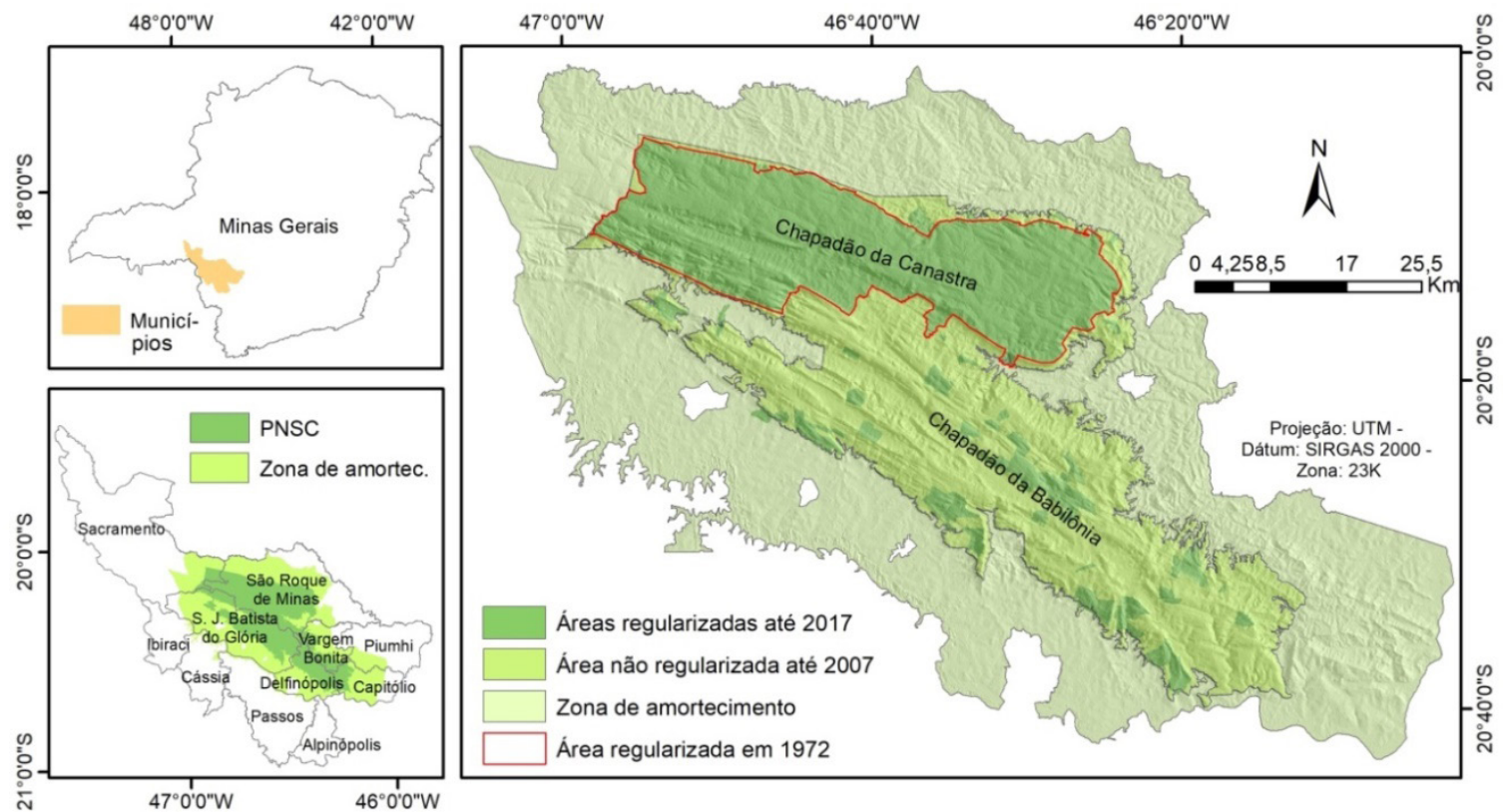

Fonte: Autores, 2019. 


\section{Materiais e métodos utilizados}

Para o desenvolvimento deste artigo, foi realizada uma extensa reunião de artigos, livros, relatórios, leis, dissertações e teses que tratam do PNSC. Foram também adquiridos dados primários em páginas na internet, como a do Instituto Brasileiro de Geografia e Estatística (IBGE) e a do Sistema IBGE de Recuperação Automática (IBGE). Além do mais, foi gerado um banco de materiais cartográficos, formado por mapas, arquivos vetoriais e produtos de teledetecção (Tabela 1).

Tabela 1: Materiais cartográficos utilizados na pesquisa.

\begin{tabular}{|c|c|c|c|c|}
\hline Materiais cartográficos & 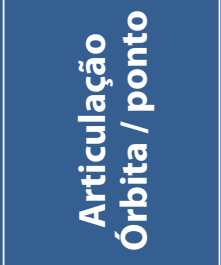 & 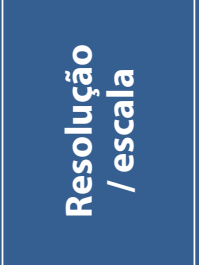 & $\stackrel{\circ}{\frac{2}{4}}$ & $\begin{array}{l}\text { 巳ँ } \\
\text { है } \\
\text { ㄴ. }\end{array}$ \\
\hline ASTER GDEM 2 & 0S21W047 e & $30 m$ & 2011 & NASA \\
\hline ASTER GDEM 2 & 0S21W048 & $30 \mathrm{~m}$ & 2011 & NASA \\
\hline Grande estatística de Minas Gerais & - & - & 2016 & IBGE \\
\hline Landsat 8 - sensor Operation Land Imager & $219 / 74$ & $30 \mathrm{~m}$ & 2018 & NASA \\
\hline Landsat 8 - sensor Operation Land Imager & $220 / 74$ & $30 \mathrm{~m}$ & 2018 & NASA \\
\hline Limites do PNSC & - & - & 2012 & ICMBio \\
\hline Limites da zona de amortecimento do PNSC & - & - & 2014 & PNSC \\
\hline Limites das zonas regularizadas do PNSC & - & - & 2017 & PNSC \\
\hline Malha municipal de Minas Gerais & - & - & 2017 & IBGE \\
\hline Mapa das províncias estruturais do Brasil & - & $1: 1.000 .000$ & 2017 & CPRM \\
\hline Mapa de compartimentação do relevo do PNSC & - & $1: 500.000$ & 2004 & MMA; IBAMA \\
\hline Mapa de solos de Minas Gerais & Folha 3 & $1: 650.000$ & 2010 & UFV et al. \\
\hline Mapa geológico de Minas Gerais & - & $1: 1.000 .000$ & 2003 & CPRM \\
\hline Mapa geomorfológico & SF.23/24 & $1: 1.000 .000$ & 1983 & RADAM-BRASIL \\
\hline Recursos naturais do Brasil: geomorfologia & - & $1: 250.000$ & 2018 & IBGE \\
\hline
\end{tabular}

- Não se aplica ou não há informação disponível.

Fonte: Autores, 2019. 


\section{Metodologia para a caracterização física}

De modo geral, a caracterização física desta pesquisa foi realizada por meio da síntese e da discussão de materiais bibliográfico e cartográfico preexistentes. Grande parte dos mapas temáticos foi obtida em formato vetorial, e, no ArcGIS 10.2, estes mapas foram reprojetados em Universal Transversa de Mercator (UTM) e dátum SIRGAS 2000, zona 23J. Este software foi também utilizado na digitalização de mapas em formato matricial, a partir de ferramentas do aplicativo Edit, além gerar layouts para a área de estudo.

Devido à ausência de algumas folhas topográficas do PNSC em formato digital, a drenagem foi extraída do modelo ASTER GDEM 2, por meio da execução de funções do Hydrology, contido no ArcGIS 10.2. O modelo citado foi também utilizado na construção do mapa hipsométrico, mediante o agrupamento de valores de elevação do MDE em classes altimétricas, por intervalos iguais e com amplitude de valores de $100 \mathrm{~m}$ entre as classes.

\section{Metodologia para o mapeamento do uso do solo}

Os procedimentos técnicos de classificação de imagens para a geração do mapa de uso do solo do PNSC foram realizados no ENVI 5.3. Foram utilizadas imagens do sensor Operation Land Imager (OLI), que está a bordo no satélite Landsat 8. Este sensor é composto de sete bandas espectrais, apresenta resolução espacial de $30 \mathrm{~m}$, temporal de 16 dias e radiométrica de 16 bits. As imagens das duas cenas foram obtidas pelo Earth Explorer (USGS, 2018). Foram adquiridas imagens de 4 de julho de 2018, para a cena 220/74, e de 29 de julho de 2018, para a cena 119/74.

Foram solicitadas imagens com processamentos prévios, como correções geométrica e atmosférica (reflectância na superfície). No ENVI 5.3, foram realizados o mosaico das duas cenas e o recorte da área. Foi gerada a composição colorida 5R/4G/6B, e, para melhorar a qualidade visual das imagens, aplicou-se o realce linear $2 \%$. Para o mapeamento de uso do solo, foram aplicadas técnicas de classificação orientada a objetos, que, embora seja mais amplamente aplicada em imagens de alta resolução espacial, mostra robustez também para imagens de média resolução espacial (GARÓFALO et al., 2015). A proposta da classificação orientada a objetos inclui duas etapas principais: a segmentação das imagens e a construção de um conjunto de treinamento (ZHOU et al., 2015).

A segmentação é o particionamento de imagens em objetos homogêneos ou com características espectrais, espaciais e de textura semelhantes (HAMEDIANFAR, SHAFARI, 2014). Este processo busca classificar áreas homogêneas, e não pixels, como no caso 
da classificação pixel a pixel. No processo de segmentação, aplicado no ENVI, foram considerados os limiares 30, no segment setting, e 80, para merge setting. Estes valores foram escolhidos por tentativa e erro.

Na sequência, foram definidas oito classes de usos do solo: 1) campos; 2) culturas temporárias; 3) culturas permanentes; 4) silvicultura; 5) mata; 6) água; 7) solo exposto; e 8) sombra. No momento de obtenção de amostras de treinamento, houve a necessidade de se fragmentarem as classes (por exemplo: solo exposto seco e solo úmido). Foram selecionadas, de forma visual, em torno de 80 amostras para cada classe, pelo arquivo segmentado sobreposto à composição colorida.

O processo de classificação foi realizado pelo Support Vector Machine, que produz resultados de maior precisão em comparação com as técnicas tradicionais. Neste método, as amostras são consideradas linearmente separáveis em um espaço n-dimensional, e a formação de hiperplano, com base em uma função Kernel e parâmetros fornecidos pelo usuário, é que separa o conjunto de dados de treinamento (OTUKEI, BLASCHKE, 2010).

Para comprovar a qualidade da classificação, realizou-se o cálculo da acurácia. Para isto, foram sorteadas 50 amostras para cada uso, que foram avaliadas com base na composição colorida utilizada no mapeamento, em imagens do Google Earth e pelo reconhecimento da área de estudo por meio de trabalhos de campo. Foram utilizados os índices Kappa e da exatidão global (CONGALTON, GREEN, 1999), e os dados foram tabulados e calculados em planilhas no BrOffice Calc 5.

\section{Metodologia para a caracterização populacional dos municípios}

Os valores de população absoluta e de situação de domicílio, referentes aos municípios que compõem o PNSC e sua ZA, foram extraídos do Censo Demográfico 2010, por meio do Sistema IBGE de Recuperação Automática (SIDRA) (tabela 1378) (SIDRA, 2017). Os dados foram organizados pelo LibreOffice Calc 5, que foi empregado na geração de gráficos pelo assistente de gráfico.

No ArcGIS 10.2, foi importada a malha municipal de Minas Gerais, da qual foram extraídos apenas os municípios estudados, e o arquivo gerado foi combinado aos dados populacionais. Para mostrar a população absoluta dos municípios, optou-se por símbolos proporcionais, que foram associados a diagramas de setores, mostrando a situação de domicílio.

O arquivo vetorial Grade Estatística oferece dados coletados pelo Censo Demográfico de 2010, em grades regulares de 1 x $1 \mathrm{~km}$, no caso de áreas rurais (IBGE, 2016). Sendo

D D D Revista da Associação Nacional de Pós-graduação e Pesquisa em Geografia (Anpege).

D D p.71-112, V.15, n.27, mai./ago. 2019. 
assim, ele permitiu avaliar a distribuição populacional, no PNSC e sua ZA, em habitantes por quilômetros quadrados (hab./ $\mathrm{km}^{2}$ ). No ArcGIS 10.2, foram geradas cinco classes de densidade populacional pela técnica de quebras naturais.

\section{Metodologia para a caracterização econômica dos municípios}

Os valores de Produto Interno Bruto (PIB) per capita e da participação dos setores primário, secundário e terciário na economia foram obtidos por intermédio do IBGE cidades (IBGE, 2017). Os valores foram organizados no LibreOffice Calc 5, e, no ArcGIS 10.2, foram associados com o arquivo vetorial de municípios. Nesse software, foi gerado um mapa que representa a participação dos setores da economia por município, por meio de colunas.

Em relação às principais atividades ligadas ao setor primário, o número de cabeças pelo tipo de rebanho foi adquirido por meio da Pesquisa da Pecuária Municipal (PPM) (tabela 3939) do ano de 2016. Os dados de área colhida dos principais cultivos agrícolas foram obtidos pela Produção Agrícola Municipal (PAM) (tabelas 1612 e 1613) do ano de 2016. Em relação aos setores secundário e terciário, o número de empresas por grupo e as principais atividades foram adquiridos pelo Cadastro Central de Empresas (tabela 1735) de 2015. Os dados foram adquiridos no portal SIDRA.

Para realizar a classificação da estrutura fundiária dos municípios, foram extraídos dados do Censo Agropecuário de 2006, por meio do SIDRA (tabela 787). O Instituto Nacional de Colonização e Reforma Agrária (INCRA) classifica as propriedades rurais conforme módulos fiscais. Embora sejam semelhantes, os valores de módulos fiscais variam entre os municípios. Por isso, foi necessário realizar uma generalização dos valores, buscando também harmonizá-los conforme os intervalos dos dados disponibilizados pelo Censo Agropecuário. Foram criados os seguintes intervalos: 1) minifúndio: imóveis com área inferir a 20 ha; 2) pequena propriedade: imóveis entre 20 e 100 ha; 3) média propriedade: imóveis entre 100 e 500 ha; e 4) grande propriedade: imóveis acima de 500 ha.

\section{Caracterização física do PNSC}

\section{Geologia}

A plataforma brasileira pode ser subdividida em domínios ou províncias estruturais, havendo continuidade geográfica e características geológicas e evolutivas (PIRES, 2012). A região que engloba o PNSC, considerando também a sua zona de amortecimento, está localizada entre três diferentes domínios, sendo eles: Tocantins, São Francisco e Paraná (Figura 2). 
Figura 2: Províncias estruturais do Escudo Atlântico que abrangem o PNSC.

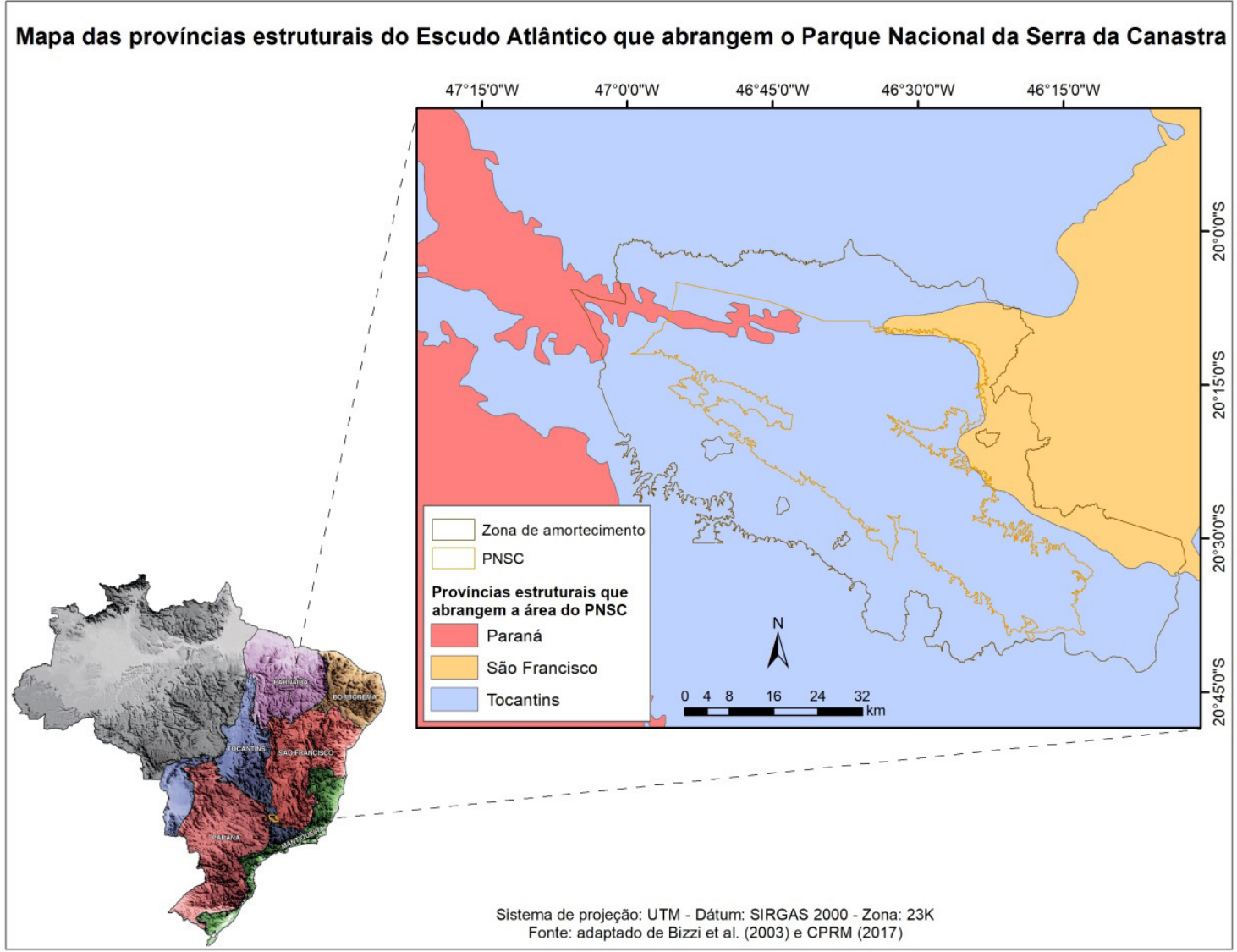

Fonte: Adaptado de Bizzi et al. (2003) e CPRM (2017).

Grande parte do PNSC e de sua ZA está sob a província estrutural do Tocantins. Esta província constitui-se em um sistema de orógenos brasilianos, caracterizado por cinturões de dobras e empurrões, denominados faixas de Brasília, Paraguai e Araguaia, e pela colisão de três blocos continentais, sendo estes: Cráton Amazonas, Cráton São Francisco e Cráton Paranapanema. O embasamento é composto de terrenos arqueanos e paleoproterozoicos, retrabalhados no ciclo brasiliano (BIZZI et al., 2003).

A porção leste da zona de amortecimento está sob a província São Francisco, onde, juntamente com a província Borborema, são encontradas as rochas mais antigas do Brasil (BIZZI et al., 2003). Esta porção está associada a um extenso núcleo cratônico, estabilizado no fim do ciclo transamazônico, circundado por faixas de dobramentos proterozoicas (PIRES, 2012). Além disso, um pequeno trecho desta porção, situado a oeste do Chapadão da Canastra e de sua ZA, está sob a bacia Paraná, que corresponde a uma bacia sedimentar de cobertura resultante da estabilização da Plataforma Sul-Americana. Esta bacia se

D

D

D Revista da Associação Nacional de Pós-graduação e Pesquisa em Geografia (Anpege).

D D

p.71-112, V.15, n.27, mai./ago. 2019. 
formou em duas fases evolutivas: talassocrática (que se desenvolveu entre o Eosiluriano e Eucarbonífero, com diversas transgressões e regressões marinhas) e geocrática (entre o Neocarbonífero e o Triássico, deposição continental e ingressões marinhas) (PIRES, 2012).

Em relação à geologia, a serra da Canastra "configura-se em um arranjo estrutural complexo, de modo que o comportamento estratigráfico entre as diversas unidades précambrianas presentes ainda não se encontra perfeitamente estabelecido" (CHAVES et. al., 2008, p. 300). O arcabouço geológico do PNSC é composto de grupos geológicos, como: Araxá, Canastra e Bambuí (Figura 3).

Figura 3: Mapa de unidades geológicas do PNSC.

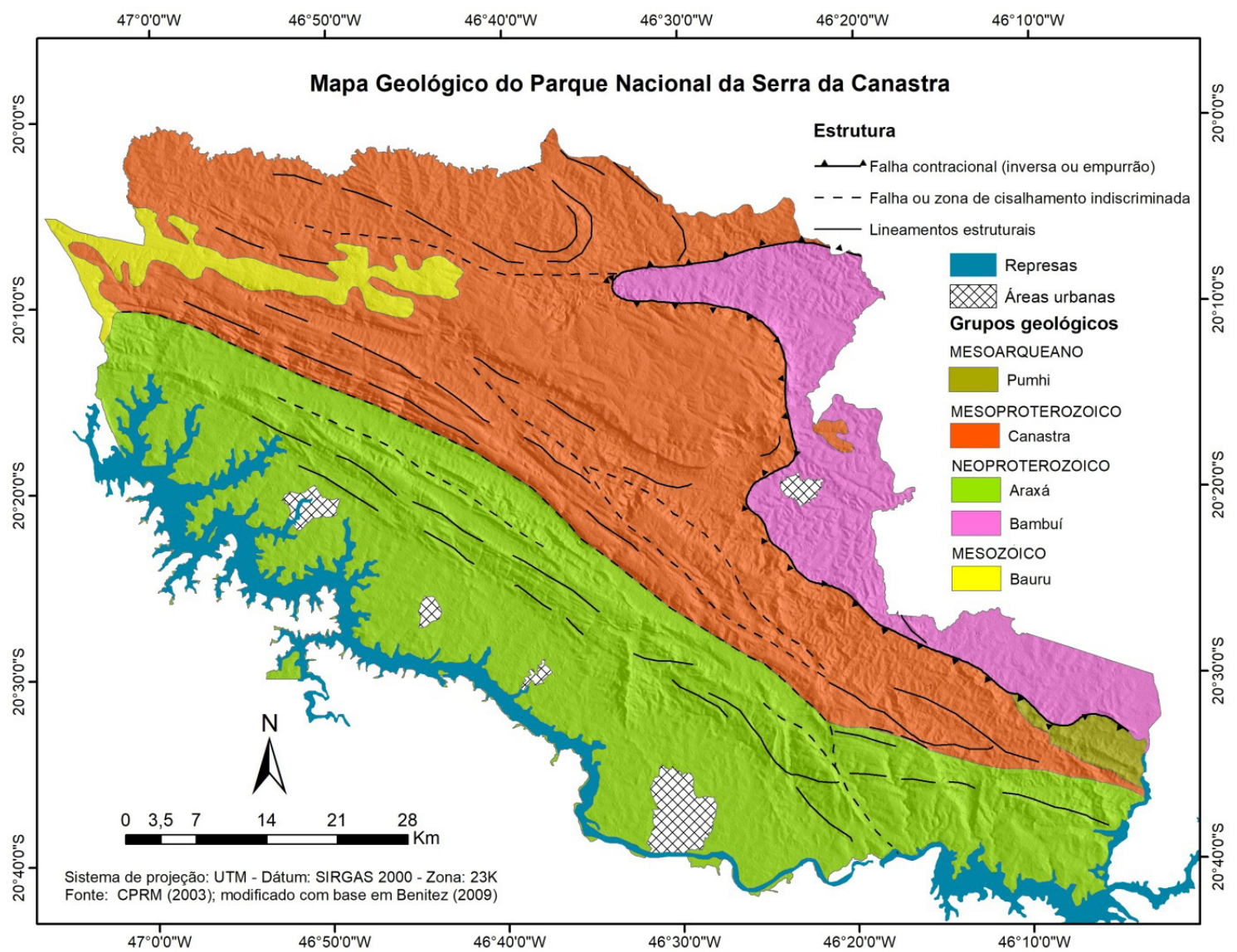

Fonte: Adaptado de CPRM (2003) e Benitez (2009).

Grande parte do parque está associada ao grupo Canastra, do Mesoproterozoico, que abrange quase todo o Chapadão da Canastra e parte do Chapadão da Babilônia, assim como o trecho norte da ZA. Os quartzitos são predominantes, mostrando coloração branca e granulação fina, com intercalações métricas locais de filitos sericíticos. Os xistos são pouco variados, em termos composicionais, incluindo sericita-quartzoxistos, quartzoxistos 
e, localmente, grafitaxistos (CHAVES et al., 2008). Estes materiais sustentam tanto as zonas elevadas dos chapadões, como as encostas e os vales. Nas bordas dos chapadões, há inclinações abruptas delineando segmentos estruturais individualizados, no sentido NW-SE (MMA, IBAMA, 2005).

O grupo Araxá está localizado ao sul do Chapadão da Babilônia, assim como em toda a área sul da ZA, em contato com o rio Grande. Datado do Neoproterozoico (CHAVES et al., 2008), este grupo é constituído predominantemente de filitos e micaxistos (MMA, IBAMA, 2005). A faixa de domínio entre os grupos Canastra e Araxá é marcada por forte estrutura tectônica de cavalgamento, com transporte de SW para NE. A zona de empurrões possui direção entre $\mathrm{N} 45^{\circ}-65^{\circ} \mathrm{W}$, assinalada por drenagens bem encaixadas e grande escarpa verticalizada (CHAVES et al., 2008).

Os metassedimentos do grupo Bambuí (Neoproterozoico) englobam siltitos, calcários e conglomerados, ocorrendo a leste da área, na ZA. Este grupo se formou sob a província estrutural do São Francisco, e suas características se diferem bastante do interior do parque, por serem terrenos menos elevados e que formam predominantemente morros alongados e colinas com vertentes convexas (MMA, IBAMA, 2005).

Um pequeno trecho a sudeste da área de estudo está sob o grupo Piumhi (Mesoarqueano), uma sequência xistosa vulcano-sedimentar arqueana do tipo greenstone belt, onde estão localizadas as rochas mais antigas. Além disso, há trechos da ZA e do Chapadão da Zagaia relacionados ao grupo Bauru, constituído por arenitos e conglomerado basal (CHAVES et. al., 2008).

\section{Geomorfologia e pedologia}

Os domínios morfoestruturais compreendem os maiores táxons da compartimentação do relevo, organizando os fatos geomorfológicos conforme o arcabouço geológico. $\mathrm{O}$ território brasileiro pode ser compartimentado em quatro domínios de idades geológicas distintas (Figura 4A). O PNSC e sua ZA estão sob os Cinturões Móveis Neoproterozoicos, que estão relacionados a extensas áreas representadas por planaltos, alinhamentos serranos e depressões interplanálticas, em terrenos dobrados e falhados, incluindo, principalmente, metamorfitos e granitóides associados (IBGE, 2009).

O segundo táxon (regiões geomorfológicas) representa compartimentos inseridos nos conjuntos litomorfoestruturais que, sob a ação dos fatores climáticos pretéritos e atuais, apresentam características genéticas comuns, agrupando feições semelhantes, associadas

D D D Revista da Associação Nacional de Pós-graduação e Pesquisa em Geografia (Anpege).

D D p.71-112, V.15, n.27, mai./ago. 2019. 
às formações superficiais e às fitofisionomias (IBGE, 2009). Grande parte da área de estudo está sob os planaltos da Canastra, mas se destacam, também a leste, terrenos sob as depressões do São Francisco (Figura 4B).

Figura 4: Unidades morfoestruturais do Brasil e regiões geomorfológicas que abrangem o PNSC.

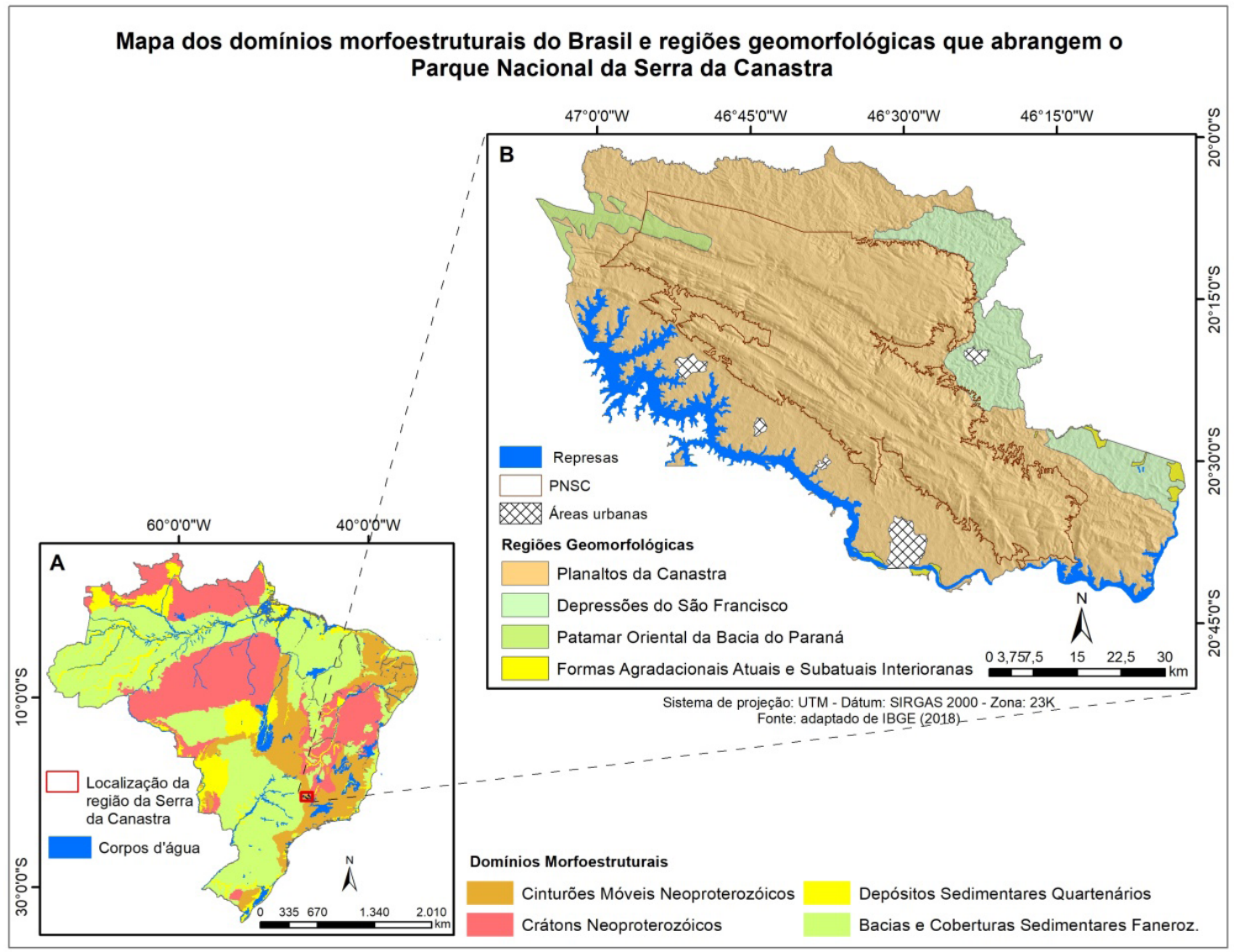

Fonte: Adaptado de IBGE (2018).

A região dos planaltos da Canastra é constituída pelas cristas, barras e vales adaptados à estrutura direcionada no sentido NW-SE. Destacam-se falhas indiscriminadas e falhas de empurrão, além de sinclinais e anticlinais. Braquissinclinal e dobras de menor amplitude condicionam o relevo. A região é cortada pela drenagem do rio Grande, afluente do rio Paraná (RADAMBRASIL, 1983).

Os planaltos da Canastra englobam duas unidades geomorfológicas que ocorrem em níveis topográficos distintos: a serra da Canastra e os Patamares da Canastra (Figura 5). As unidades geomorfológicas estão associadas ao terceiro táxon, definido como um arranjo de formas altimétricas e fisionomicamente semelhantes. Estas unidades evidenciam seus processos originários, formações superficiais e tipos de modelados. O comportamento da 
drenagem, os padrões e as anomalias são tomados como referencial, pois revelam as relações entre os ambientes climáticos atuais ou passados, assim como as condicionantes litológicas ou tectônicas (IBGE, 2009). Na área de estudo desta pesquisa, as unidades geomorfológicas se associam, também, às características hipmométricas (Figura 6).

A unidade Patamares da Canastra está dividida, de modo geral, em dois setores. No setor norte, posicionado geralmente acima de $1.000 \mathrm{~m}$ de altitude, forma, junto à serra da Canastra, o divisor de águas das bacias dos rios São Francisco e Paraná. O setor sul está associado à área rebaixada, entre 600 e 750m. Em função do tipo de modelado, das formações superficiais e da facilidade na obtenção de água, esta área é aproveitada para a agricultura e a pecuária (RADAMBRASIL, 1983). No interior do PNSC, essa unidade forma a depressão intermontana que separa os chapadões da Canastra e da Babilônia.

Figura 5: Mapa de unidades geomorfológicas do PNSC.

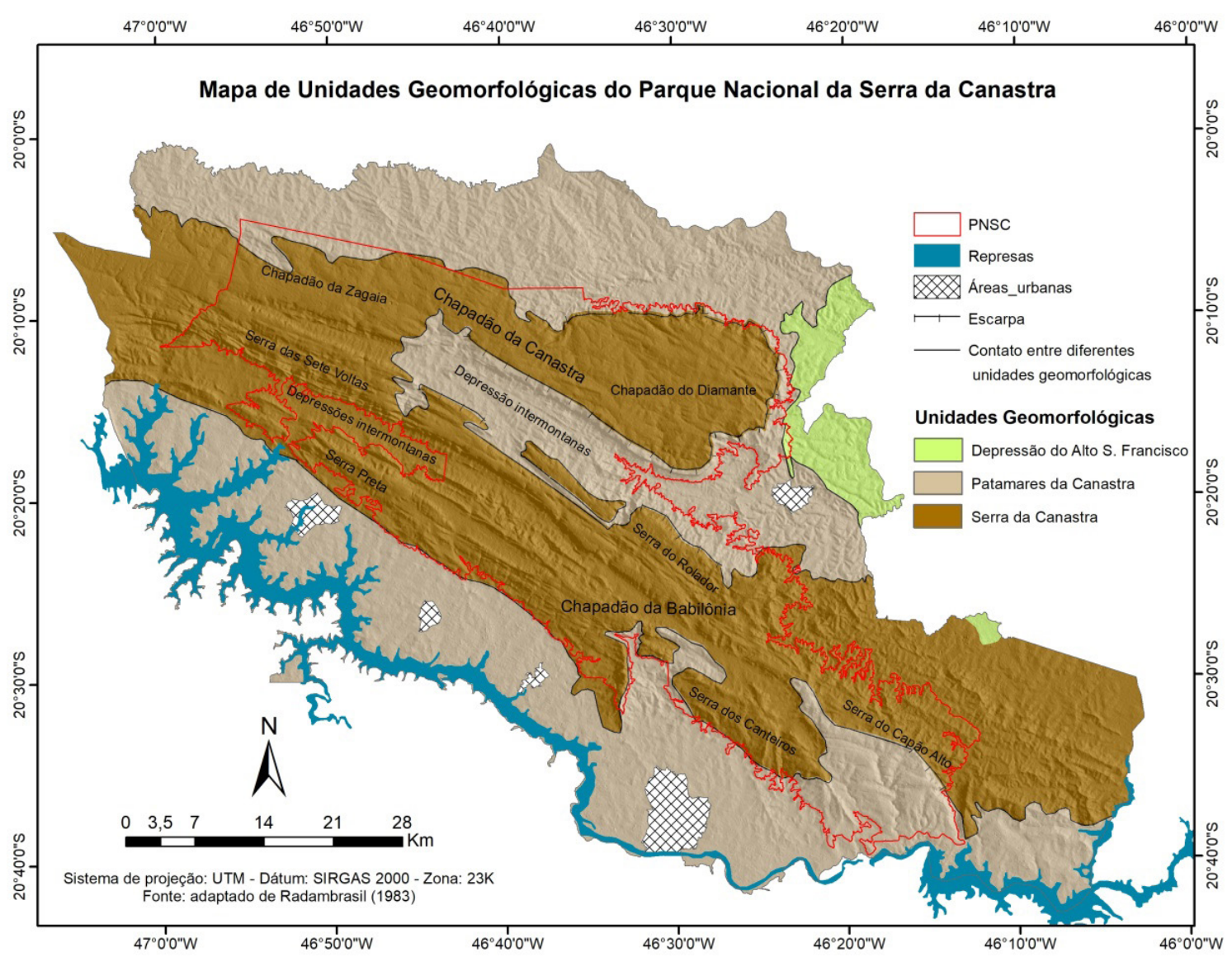

Fonte: Adaptado de Radambrasil (1983).

D

D D p.71-112, V.15, n.27, mai./ago. 2019. 
Figura 6: Mapa hipsométrico do PNSC.

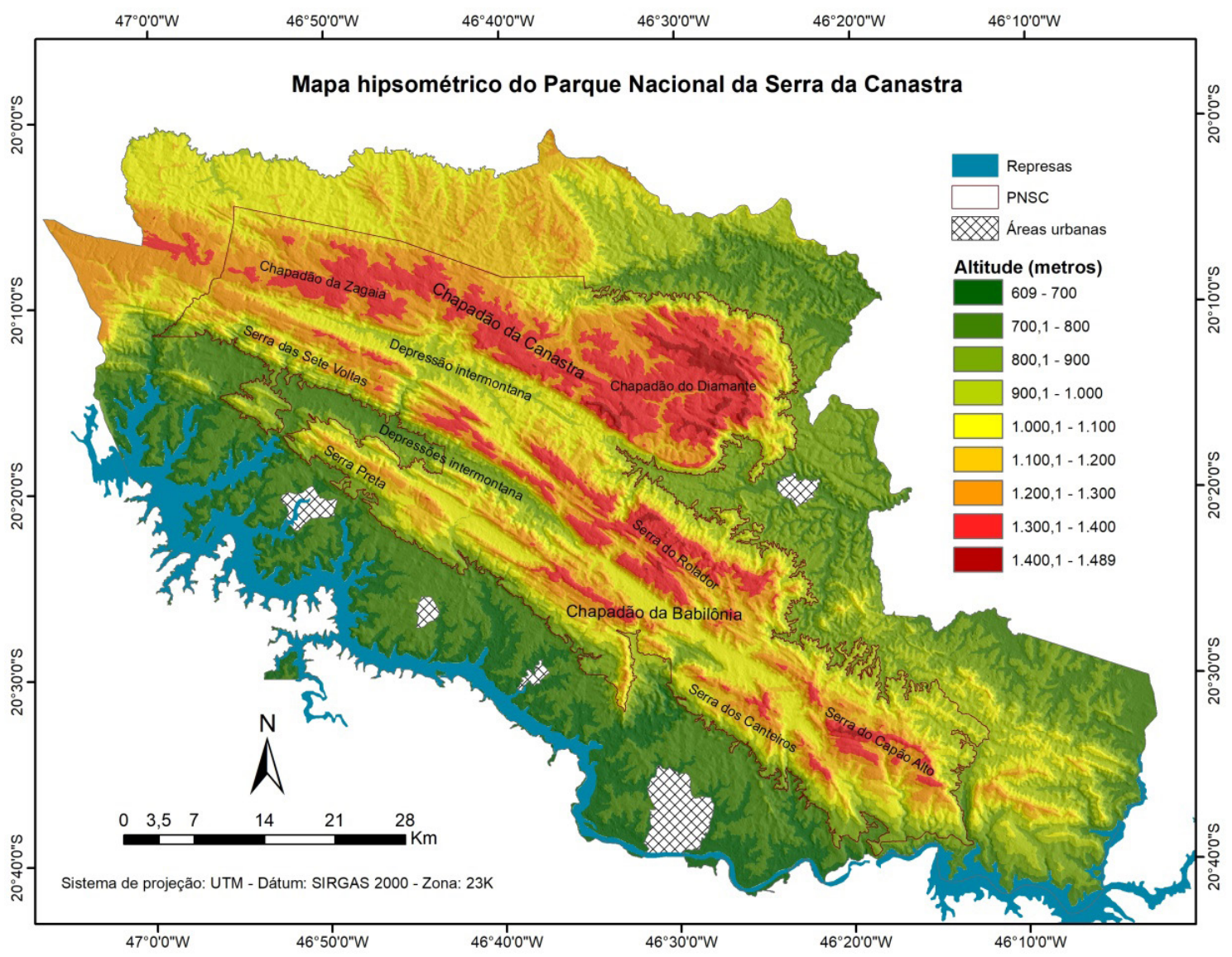

Fonte: Autores, 2019.

A unidade geomorfológica da serra da Canastra está emoldurada pelos Patamares da Canastra. Esta unidade forma os chapadões da Canastra e da Babilônia. Os topos destes chapadões são planos e elevados a cerca de $1.400 \mathrm{~m}$ de altitude, e são heranças de superfícies de aplanamento que truncaram os topos desta estrutura, em que as camadas mostram mergulhos de até $65^{\circ}$ (RADAMBRASIL, 1983). A serra da Canastra se configura como uma verdadeira serra residual, e os extensos topos planos com aspecto de chapadas estão associados a superfícies de erosão, que remontam ao pré-Cretáceo, com reafeiçoamento no Terciário-Quaternário. Formam-se alinhamentos de cristas, ora com bordas anticlinais interiormente erodidas, ora em abas de sinclinais alçadas (ROSS, 1985).

Um trecho a leste da ZA se encontra sob a região geomorfológica Depressões do São Francisco. De modo geral, esta região está associada à unidade geomorfológica Depressão do Alto São Francisco, onde está localizada a alta bacia hidrográfica do rio São Francisco. O arranjo espacial das feições que caracterizam o quadro morfológico desta unidade apresenta 
diversos tipos de modelados resultantes da dissecação, do aplainamento, da dissolução e da acumulação fluvial, desenvolvidos em climas pretéritos e atuais (RADAMBRASIL, 1983).

Em escala de maior detalhe, o relevo do PNSC pode ser fragmentado, segundo o MMA e o IBAMA (2005), em cinco compartimentos: chapadas, colinas amplas suavemente onduladas, depressões intermontanas, morros elevados e alongados, morros alongados e colinas com vertentes convexas (Figura 7). Estes compartimentos estão sujeitos às mesmas condicionantes climáticas, porém, apresentam características topográficas, morfológicas e pedológicas distintas (MMA, IBAMA, 2005).

Ao longo dos compartimentos de relevo, são encontrados solos, muitos deles pouco desenvolvidos ou em associação com afloramentos rochosos (Figura 8). Na maioria das vezes, no cerrado, os solos são pouco profundos, com baixa fertilidade natural e acidez acentuada em razão da presença de sílica, em relevos planos ou suavemente ondulados (BASTOS, FERREIRA, 2010).

O compartimento dessas chapadas pode ser fragmentado em três subdivisões: 1) ao norte, o Chapadão da Canastra, abrangendo o Chapadão da Zagaia e o Chapadão do Diamante; 2) na porção intermediária, a parte do Chapadão da Babilônia que engloba serras, como Sete Voltas e Rolador; 3) a porção sul, também chamada de Chapadão da Babilônia, onde se encontram as serras Preta e dos Canteiros (MMA, IBAMA, 2005).

O Chapadão da Canastra pode ser considerado um ambiente relativamente plano e preservado, do ponto de vista erosivo, com variações altimétricas, de modo geral, acima de $1.200 \mathrm{~m}$, podendo ultrapassar os $1.400 \mathrm{~m}$. Grande parte de seu interior é formada por colinas, depressões nas cabeceiras e terrenos escarpados nas bordas, onde são verificadas declividades elevadas (VASCONCELOS et al., 2012). O Chapadão do Diamante é formado por neossolos litólicos, e o Chapadão da Zagaia possui maior variabilidade de solos, apresentando cambissolo háplico, latossolo vermelho, plintossolo argilúvico e associações de afloramentos rochosos e cambissolo háplico.

D

D D Revista da Associação Nacional de Pós-graduação e Pesquisa em Geografia (Anpege).

D D

p.71-112, V.15, n.27, mai./ago. 2019. 
Figura 7: Mapa de compartimentação do relevo do PNSC.

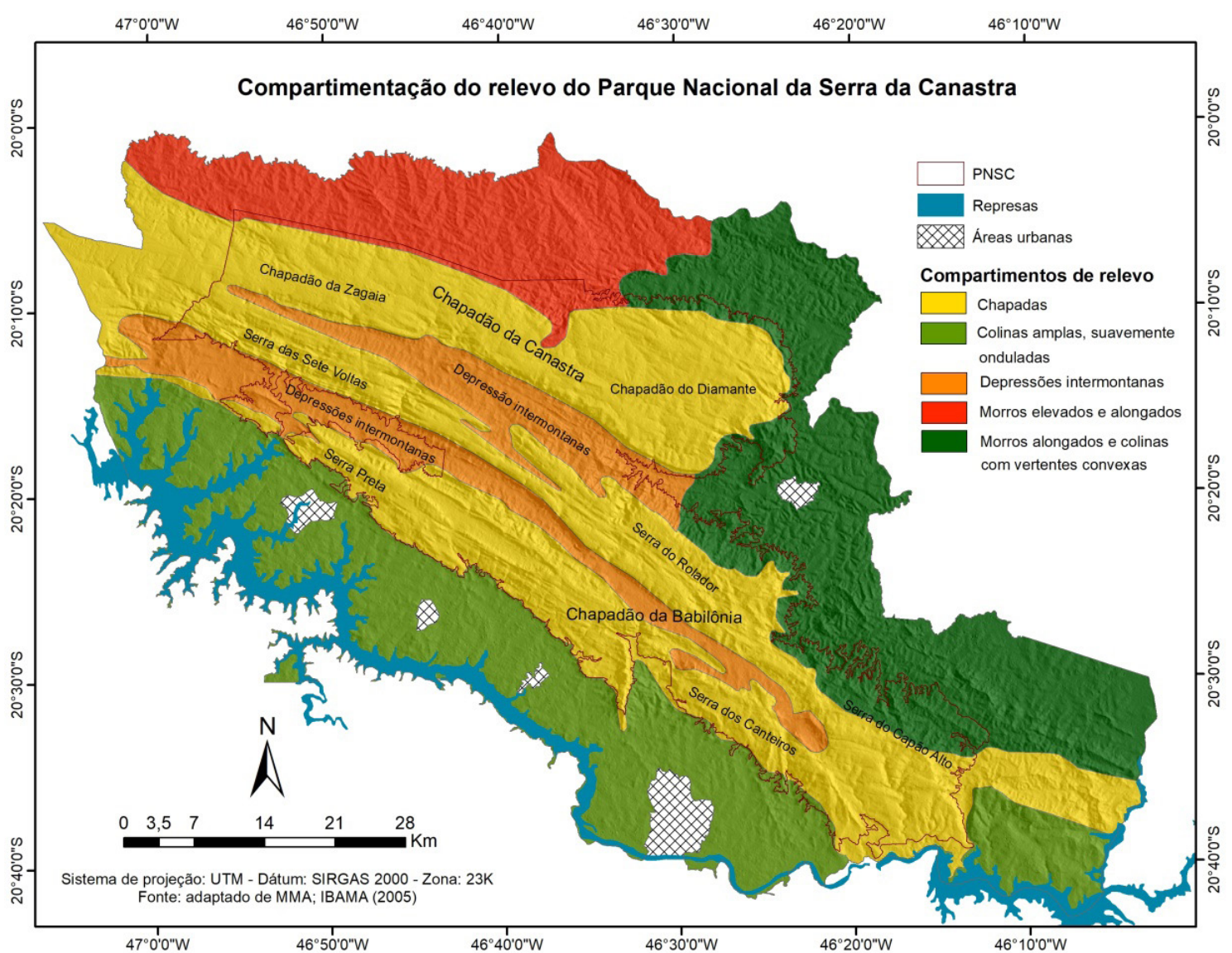

Fonte: Adaptado de MMA, IBAMA (2005). 
Figura 8: Mapa pedológico do PNSC.

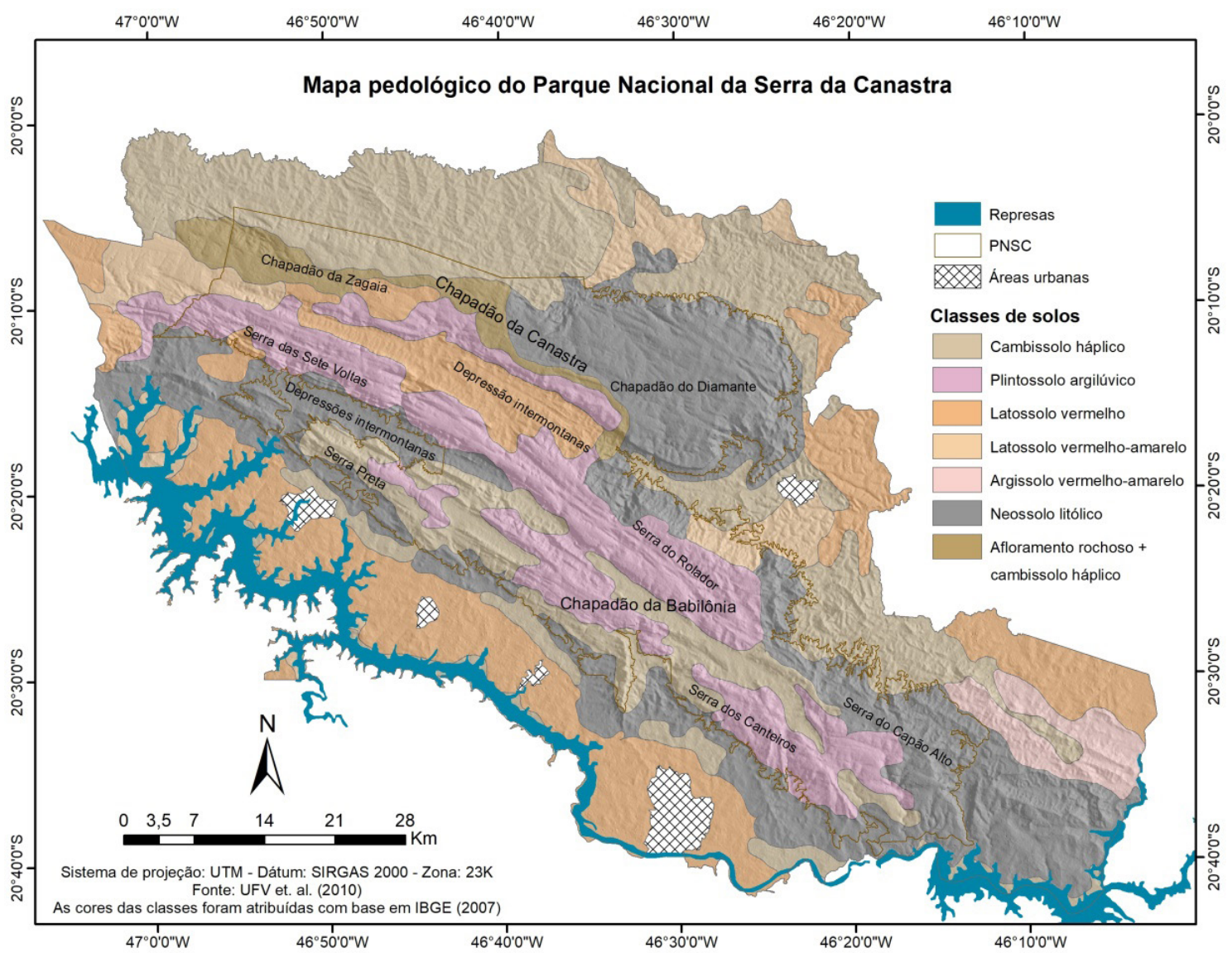

Fonte: Adaptado de UFV,CETEC, UFLA e FEAM (2010).

O Chapadão da Babilônia apresenta também altitudes elevadas, que, em seu interior, estão predominantemente acima de $1.300 \mathrm{~m}$. Nestes locais, destacam-se cristas elevadas, tendo em vista a ocorrência de relevos mais entalhados. As declividades são variadas (MMA, IBAMA, 2005), e predomina o plintossolo argilúvico, especialmente nos topos da porção intermediária, sendo que, na porção sul, ocorre também cambissolo háplico.

As depressões intermontanas são corredores rebaixados que individualizam os chapadões quartzíticos, e, nestes locais, sobressaem rochas menos resistentes que o quartzito (MMA, IBAMA, 2005). Na depressão que separa o Chapadão da Canastra e o Chapadão da Babilônia, predominam latossolos vermelhos. Na depressão situada entre os setores intermediário e sul do Chapadão da Babilônia, ocorre o neossolo litólico (entre as serras das Sete Voltas e a Preta) e o cambissolo háplico (nas proximidades com as serras do Rolador e dos Canteiros).

D

D D p.71-112, V.15, n.27, mai./ago. 2019. 
O compartimento dos morros elevados alongados está localizado a noroeste da área de estudo, dentro do perímetro da ZA, apresentando, basicamente, morros com interflúvios alongados. Neste compartimento, as rochas do grupo Canastra, em particular os quartzomica-xistos, servem de substrato, e a área está associada à bacia do rio Paraná (MMA, IBAMA, 2005). As altitudes podem variar entre 1.000 e $1.300 \mathrm{~m}$, e os principais solos são os cambissolos háplicos.

Os morros alongados e as colinas com vertentes convexas estão relacionados a trechos das porções nordeste e leste da área de estudo, estando basicamente associados à província estrutural do São Francisco e à bacia hidrográfica do rio São Francisco. No setor nordeste, os morros são constituídos por interflúvios alongados, e, à medida que se aproximam do município de Vargem Bonita, as vertentes se tornam mais amplas e convexas, assumindo fisionomia colinosa (MMA, IBAMA, 2005). As altitudes variam de 700 a $1.000 \mathrm{~m}$, verificando-se ali cambissolos háplicos, latossolos vermelhos, latossolos vermelho-amarelo e argissolos vermelho-amarelo.

As colinas amplas, suavemente onduladas, estão localizadas na porção da ZA que vai de noroeste a sudeste. Este relevo é caracterizado por amplas colinas de topos aplainados e vertentes convexas e rampeadas, predominantemente de baixa declividade (MMA, IBAMA, 2005), em que se destacam altitudes entre 600 e $800 \mathrm{~m}$. O latossolo vermelho é o solo que prevalece, mas, próximos ao rio Grande, se encontram também latossolos vermelho-amarelo e cambissolos háplicos.

\section{Clima}

A área de estudo está inserida no domínio morfoclimático do cerrado, que tem como clima predominante o tropical sazonal (COUTINHO, 2002). Estudos realizados apontam que, nos topos dos chapadões, pode ser observado o clima subtropical (quente e chuvoso, no verão, e moderadamente frio e seco, no inverno). Nessa área, a temperatura média anual gira em torno de 18 a $20^{\circ} \mathrm{C}$, a precipitação anual varia em torno de 1.500 a 1.800 mm e as chuvas se concentram entre novembro e março, quando ocorre a estação chuvosa (Figura 9) (NOVAIS, 2011). Entre maio e setembro, na estação seca, a precipitação reduz drasticamente e pode chegar a zero, durante meses (COUTINHO, 2002). 
Figura 9: Diagrama pluviométrico gerado a partir de dados obtidos no topo da serra da Canastra.

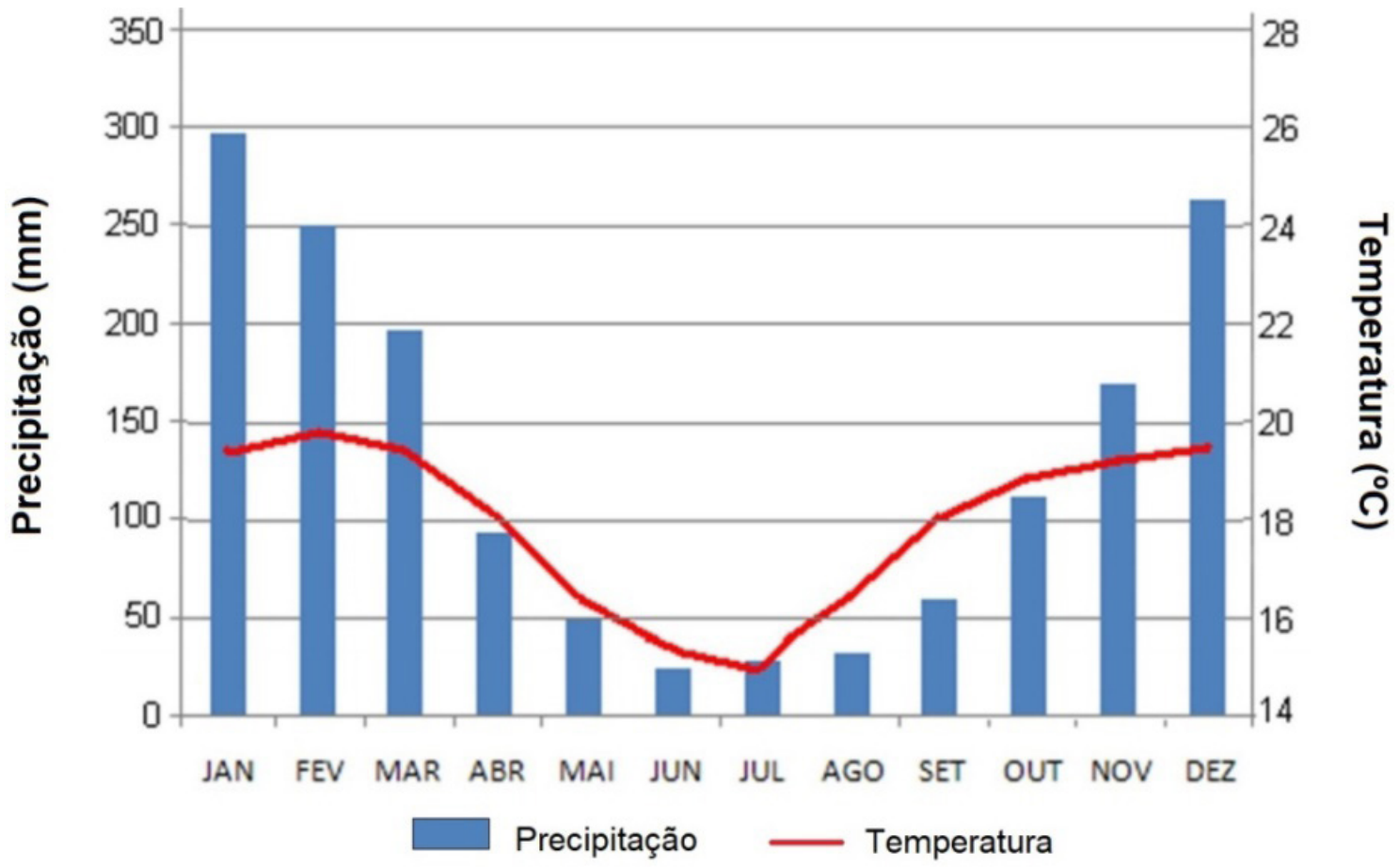

Fonte: Adaptado de Novais (2011).

Na região do cerrado, durante o outono e o inverno, são registradas as menores taxas de umidade relativa do ar (BASTOS, FERREIRA, 2010). A partir de dados de uma estação meteorológica instalada no Chapadão da Canastra, foi construído um gráfico da variação da umidade relativa do ar, ao longo do ano (Figura 10) (MMA, IBAMA, PREFOGO, PNSC, 2005), cujos resultados mostram que as menores taxas são observadas em agosto, setembro e outubro, enquanto as maiores são observadas em dezembro, janeiro e fevereiro.

Figura 10: Umidade relativa do ar mensal gerada a partir de dados obtidos no topo da serra da Canastra.

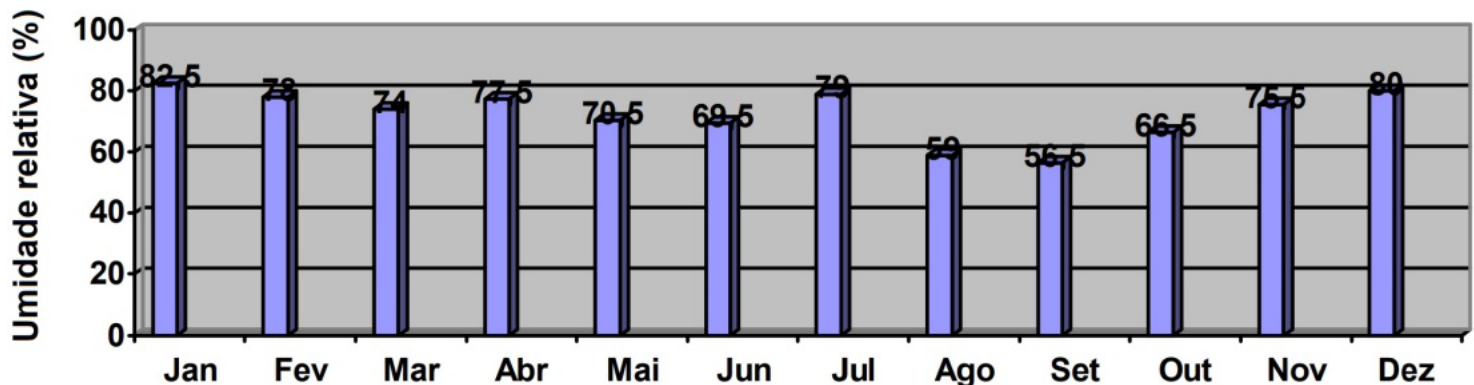

Fonte: MMA, IBAMA, PREFOGO, PNSC (2005)

D

D D p.71-112, V.15, n.27, mai./ago. 2019. 


\section{Hidrografia}

Em regiões do cerrado, há, de modo geral, perenidade dos principais cursos d’água, embora haja o desaparecimento temporário de cursos de menor ordem de grandeza, no período seco (AB'SÁBER, 2012). A região que abrange o PNSC destaca extensa rede de drenagem, e a serra da Canastra funciona como um divisor de águas de diferentes bacias hidrográficas brasileiras: rio Grande (afluente do rio Paraná), rio Paranaíba (afluente do rio Paraná) e rio São Francisco (Figura 11).

A conservação da serra da Canastra é de grande importância para a bacia do São Francisco, visto que, no Chapadão do Diamante, situa-se a nascente histórica do rio São Francisco. Este rio drena os estados de Minas Gerais, Bahia, Pernambuco, Alagoas e Sergipe e o Distrito Federal, com extensão de $3.161 \mathrm{~km}$, e sua bacia abrange uma área de 634.000 $\mathrm{km}^{2}$. Além disso, o rio São Francisco está presente em três diferentes domínios brasileiros: o cerrado, a caatinga e a Mata Atlântica (CUNHA, 2012).

Figura 11: Mapa de rede hidrográfica do PNSC.

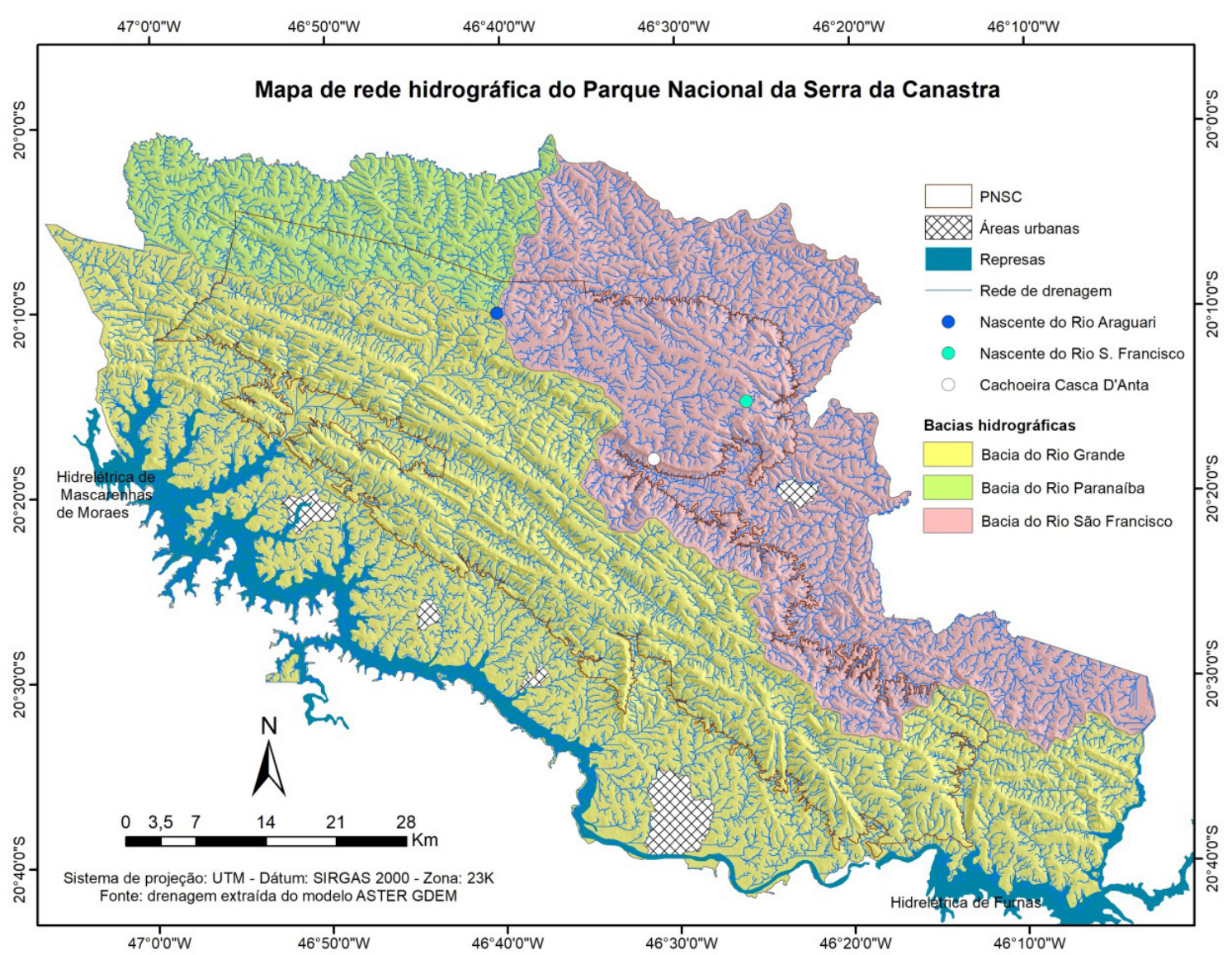

Fonte: Autores, 2019. 
A bacia do Paranaíba está associada à porção noroeste do PNSC e de sua ZA. A conservação deste parque é também de grande valor para esta bacia, visto que, no Chapadão da Zagaia, nasce o rio Araguari, que possui $475 \mathrm{~km}$ de comprimento até chegar à sua foz, no rio Paranaíba, passando por diversos municípios do Triângulo Mineiro (CBH ARAGUARI, 2013). A bacia do rio Paranaíba, com uma área de $222 \mathrm{mil} \mathrm{km}^{2}$, passa por estados como Goiás, Minas Gerais e Mato Grosso do Sul e pelo Distrito Federal (CBH PARANAÍBA, 2013).

A bacia do rio Grande tem sua nascente na serra da Mantiqueira, no município de Bocaina de Minas (MG), e abrange os estados de Minas Gerais e de São Paulo. Com uma drenagem de $143.000 \mathrm{~km}^{2}$, a bacia do rio Grande tem grande destaque pelo seu potencial hidrelétrico (CBH GRANDE, 2013). Esta bacia delimita toda a porção sul da área de estudo, e, neste local, estão instaladas diversas unidades hidrelétricas, tais como Mascarenhas de Moraes, Furnas, Luiz Carlos Barreto de Carvalho e Jaguará.

As tendências e os padrões de drenagem, especialmente no interior do PNSC, se apresentam fortemente controlados pelos sistemas de contatos litológicos paralelos na direção geral NW-SE. Há algumas exceções, como no caso do rio São Francisco, ao percorrer o Chapadão do Diamante. Desenvolvem-se padrões de drenagem, na área de estudo, principalmente, na forma de treliça e dendrítica (MMA, IBAMA, 2005).

\section{Uso do solo do PNSC}

A serra da Canastra está situada em uma área marginal de ocorrência do cerrado (MENEZES et al., 2017), um dos fatores que caracterizam as formações vegetais desta região (CONTI, FURLAN, 2011). Em razão dos usos anteriores à criação desse parque e devido ao uso do fogo pelos proprietários de terras para a renovação de pastagens, as formações florestais da região da serra da Canastra sofreram alterações em diferentes graus. Podemse encontrar algumas árvores em condições primárias, mas a maioria dos remanescentes florestais se encontra, atualmente, em estágio secundário (MMA, IBAMA, 2005).

Para se compreender as formas de utilização antrópica desse espaço e a distribuição de suas coberturas vegetais, foi gerado o mapa de uso do solo do PNSC para o ano de 2018 (Figura 12). Este mapa foi gerado por técnicas de classificação orientada a objetos e pelo algoritmo SVM, com base em imagens multiespectrais Landsat OLI. O mapeamento apresentou índice de exatidão global de 0,885 , que mostra que $88,5 \%$ das áreas amostradas foram classificadas corretamente. O índice Kappa calculado foi de 0,868, considerado excelente, de acordo com Congalton \& Green (1999).

D

D D Revista da Associação Nacional de Pós-graduação e Pesquisa em Geografia (Anpege).

D D

p.71-112, V.15, n.27, mai./ago. 2019. 
Figura 12: Mapa de uso do solo do PNSC, no ano de 2018.

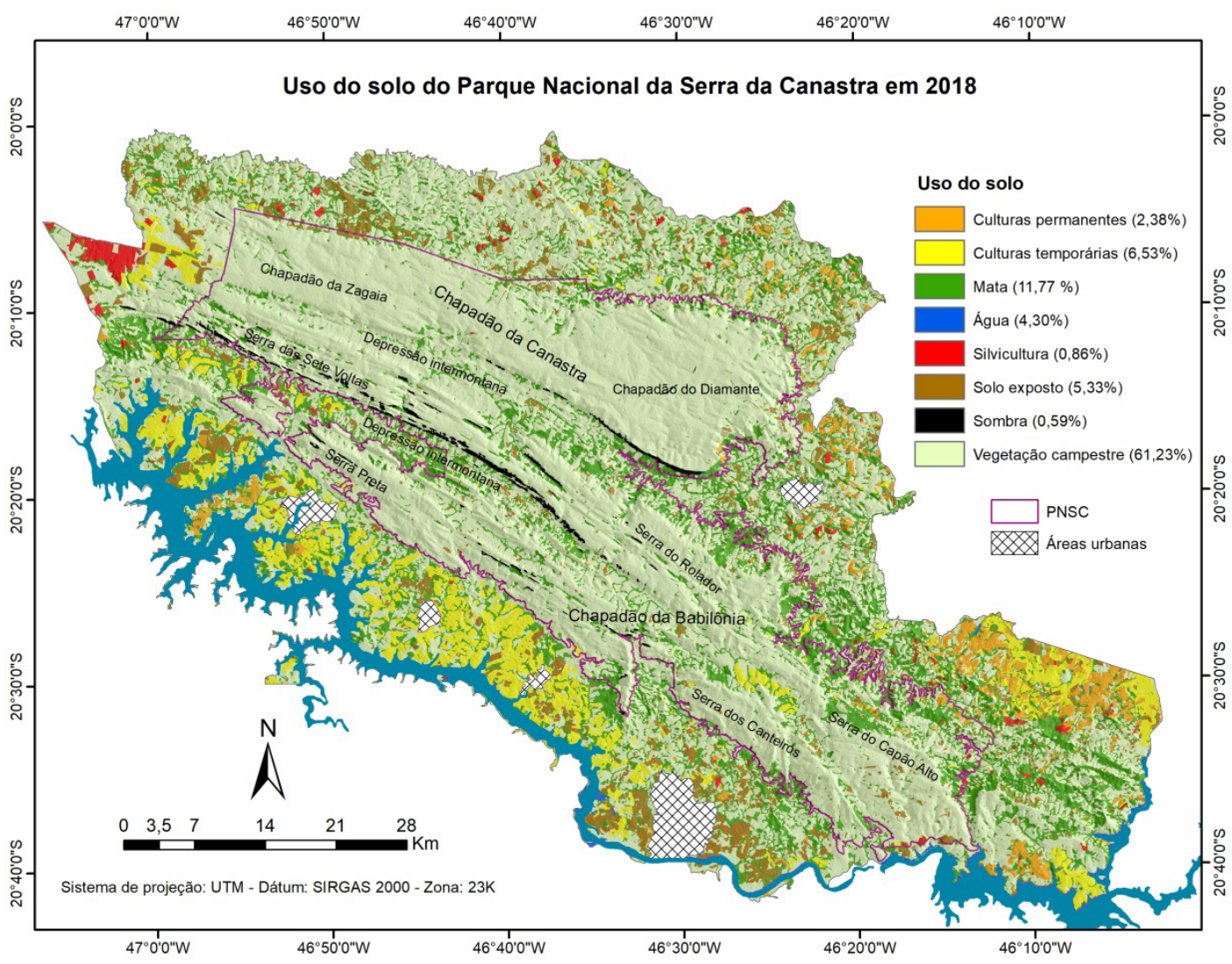

Fonte: Autores, 2019.

O mapa de uso do solo comprova que a vegetação campestre corresponde ao uso mais expressivo, sendo representada pelas fitofisionomias campo limpo, campo sujo e campo rupestre, que ocupam $61,23 \%$ da área. Estudos de Couto Junior et al. (2010) mostram que, de modo geral, no Chapadão da Canastra, os campos limpos ocorrem em altitudes variadas, entre 1.300 e $1.500 \mathrm{~m}$, porém, em declividades pouco acentuadas. Os campos sujos também ocorrem em baixas declividades, porém, se situam entre 1.400 e $1.500 \mathrm{~m}$, predominantemente. Por outro lado, os campos rupestres se localizam em paisagens mais elevadas e em declives mais acentuados.

Os campos limpos são as fitofisionomias mais presentes, no PNSC, ocupando a maior parte dos chapadões (COUTO JUNIOR et al., 2010). São constituídos por vegetação predominantemente herbácea, com raros arbustos e ausência de árvores (RIBEIRO et al., 1983). Uma característica importante é que as espécies herbáceas entram em senescência, no período seco, ressurgindo, no período chuvoso (SANTANA et al., 2010). No Chapadão da Canastra, os campos limpos se encontram mais preservados que no Chapadão da 
Babilônia (MMA, IBAMA, 2005), e, na ZA, estão mais degradados, devido ao seu uso como pastagem para a pecuária (MMA, ICMBIO, PNSC, 2018).

Os campos sujos são uma fitofisionomia herbácea-arbustiva, composta de coberturas herbáceas densas em associação com indivíduos subarbustivos, arbustivos e, com menor frequência, indivíduos arbóreos de pequeno porte (RIBEIRO, WALTER, 1998; TANNUS, ASSIS, 2004). Os campos rupestres abrangem um complexo de vegetações que agrupam diversas paisagens com espécies típicas, sobretudo herbáceas. Desenvolvem-se em afloramentos rochosos, que formam microrrelevos onde crescem indivíduos lenhosos e herbáceos. Seus arbustos podem chegar a até dois metros de altura, concentrando-se nas fendas das rochas (RIBEIRO et al., 1983; RIBEIRO, WALTER, 1998).

A classe de uso do solo mata é a segunda mais expressiva do PNSC, associando-se a 11,77\% desta área. Ocorre ao longo da ZA e das depressões intermontanas, em sua maioria, associada aos cursos d'água, formando matas ciliares. As matas ciliares acompanham rios de médio e de grande porte, sem formar galerias. As árvores podem variar entre 20 e 25 $\mathrm{m}$, mas alguns indivíduos podem chegar a $30 \mathrm{~m}$. Na estação chuvosa, a cobertura chega a $90 \%$, enquanto, na estação seca, pode ser inferior a 50\%, devido às características de deciduidade (RIBEIRO et al., 1983; RIBEIRO, WALTER, 1998).

No interior dos chapadões, ocorrem também matas de galeria, sendo estas fitofisionomias que acompanham córregos e rios de pequeno porte, formando corredores fechados (galerias). A altura média do estrato arbóreo varia entre 20 e $30 \mathrm{~m}$, fornecendo cobertura de 70 a 95\% e não apresentando deciduidade na estação seca (RIBEIRO et al., 1983; RIBEIRO, WALTER, 1998). Como as matas de galeria são normalmente estreitas, o mapeamento não permitiu que elas fossem destacadas em sua totalidade, devido à resolução da imagem utilizada no mapeamento.

As culturas temporárias representam 6,53\%, ocorrem por toda a ZA e, na área do parque, ao longo das depressões intermontanas. As maiores concentrações se situam nas proximidades do rio Grande ou a sudeste da ZA. As culturas permanentes correspondem a 2,38\%, e são mais comuns na porção leste da ZA. Já a silvicultura equivale a 0,86\%, estando associada à eucaliptocultura, e, apesar de ocorrer por toda a área, concentra-se na porção oeste da ZA. As áreas de solo exposto, que estão geralmente ligadas ao preparo do solo para a agricultura, ocupam 5,33\%, e são comumente encontradas em toda a ZA.

A classe água, que se relaciona a 4,30\%, está principalmente associada às represas formadas no rio Grande, ao sul, entretanto, há também pequenos lagos situados a oeste da ZA. Cursos d'água de pequena ordem não puderam ser identificados, devido à resolução

D D D Revista da Associação Nacional de Pós-graduação e Pesquisa em Geografia (Anpege).

D $D$ p.71-112, V.15, n.27, mai./ago. 2019. 
da imagem utilizada no mapeamento. Algumas feições foram mascaradas por sombra, especialmente nas proximidades de relevos escarpados ou muito declivosos, como ocorre no sopé dos chapadões, e esta classe abrange 0,59\% da área estudada.

\section{Caracterização populacional dos municípios que compõem o PNSC}

Até a primeira metade do século XX, os municípios da região da serra da Canastra tinham como principais atividades econômicas o cultivo de cana-de-açúcar, a pecuária e a produção de laticínios (MMA, IBAMA, 2005). Esta economia se baseava na produção rural e familiar, sendo que o contingente de populacional rural era mais elevado que a população urbana (MESSIAS, 2014). Entretanto, a segunda metade desse século foi acompanhada de transformações espaciais nessa região, que trouxeram profundas alterações na estrutura econômica e populacional dos seus municípios.

As primeiras mudanças se relacionaram à instalação de hidrelétricas, no rio Grande, o que levou à perda de terras agricultáveis e de pastagens, devido à elevação do nível de água. A hidrelétrica de Mascarenhas de Moraes (1957) alagou parte dos municípios de Delfinópolis, Cássia, Passos, Ibiraci e São João Batista do Glória; Furnas (1963) atingiu Capitólio; Luiz Carlos Barreto de Carvalho (1969) ocupou áreas de Ibiraci e Sacramento; e Jaguará (1971) inundou trechos do município de Sacramento.

Ademais, a criação do PNSC, em 1972, alterou a dinâmica de uso do solo nos municípios da região. Com a instalação dos 197.787 ha desse parque, muitos municípios perderam terras nas quais havia população assentada. Onze municípios contribuíram para a formação do parque, mas como Ibiraci, Cássia, Passos e Alpinópolis fazem parte de pequenos trechos da ZA, não sofreram grandes impactos. Além disso, apenas 71.525 ha foram regularizados, no século XX, o que causou perdas de terras pelas desapropriações apenas em Sacramento, Delfinópolis e São Roque de Minas.

As perdas de terras, pelos motivos mencionados, contribuíram com o declínio populacional que ocorreu, entre os anos de 1950 e 1980, nessa região. Os maiores declínios foram observados em Capitólio (35,20\%), Vargem Bonita e São Roque de Minas - que compunham um único município (26,79\%) - e Delfinópolis $(23,22 \%)$. Contudo, o êxodo rural fez com que a população urbana se tornasse mais elevada que a população rural, na maior parte dos municípios (MESSIAS, 2014), fenômeno também ocorrido em todo o território brasileiro, devido ao atrativo das cidades, à mecanização da agricultura e à desestruturação das antigas relações tradicionais de trabalho no campo (SCARLATO, 2011). 
Entre 1980 e 2010, ao contrário do período anterior, houve crescimento populacional em praticamente todos os municípios. A maior taxa de variação positiva foi observada em Capitólio (56,67\%), que se tornou o mais forte no setor turístico - exemplo disto foi a criação, neste município, do Escarpas do Lago, um balneário com instalações de alto padrão. Outros municípios que tiveram expansão populacional representativa foram São João Batista do Glória $(41,41 \%)$ e Sacramento $(27,10 \%)$. Por outro lado, Vargem Bonita e São Roque de Minas tiveram decréscimo populacional (-1,15\%). A população urbana, nesse período, evidenciou também índices crescentes (MESSIAS, 2014).

Dados do Censo do IBGE de 2010 mostram que os municípios que englobam a área do PNSC apresentam valores entre 2.163 (Vargem Bonita) e 23.893 habitantes (Sacramento). Já os que formam a ZA apresentam entre 2.163 (Vargem Bonita) e 106.290 habitantes (Passos) (Tabela 2, Figura 13). Além disso, com exceção de Passos e Piumhi, que são os dois municípios com maiores números populacionais absolutos, o percentual de população urbana é inferior à média do estado de Minas Gerais.

Tabela 2: Dados populacionais referentes aos municípios que compõem o PNSC.

\begin{tabular}{cccc|c|c}
\multirow{2}{*}{ Município } & \multicolumn{3}{c|}{ População (absoluta) } & \multicolumn{2}{c}{ População (\%) } \\
\cline { 2 - 6 } & Total & Urbana & Rural & Urbana & Rural \\
\hline Vargem Bonita & 2.163 & 1.142 & 1.021 & 53 & 47 \\
\hline São Roque de Minas & 6.686 & 4.222 & 2.464 & 63 & 37 \\
\hline Delfinópolis & 6.830 & 4.846 & 1.984 & 71 & 29 \\
\hline S. João Batista do Glória & 6.887 & 5.607 & 1.280 & 81 & 19 \\
\hline Capitólio & 8.183 & 6.502 & 1.681 & 79 & 21 \\
\hline Ibiraci & 12.176 & 8.208 & 3.968 & 67 & 33 \\
\hline Cássia & 17.412 & 14.221 & 3.191 & 82 & 18 \\
\hline Alpinópolis & 18.488 & 14.990 & 3.498 & 81 & 19 \\
\hline Sacramento & 23.896 & 19.275 & 4.621 & 81 & 19 \\
\hline Piumhí & 31.883 & 28.564 & 3.319 & 90 & 10 \\
\hline Passos & 106.290 & 100.842 & 5.448 & 95 & 5 \\
\hline Minas Gerais & 19.597 .330 & 16.715 .216 & 28.82 .114 & 85 & 15 \\
\hline
\end{tabular}

Fonte dos dados: Censo Demográfico de 2010, adquiridos pelo SIDRA (2017).

D 
Figura 13: Distribuição espacial da população e situação de domicílio nos municípios que abrangem o PNSC.

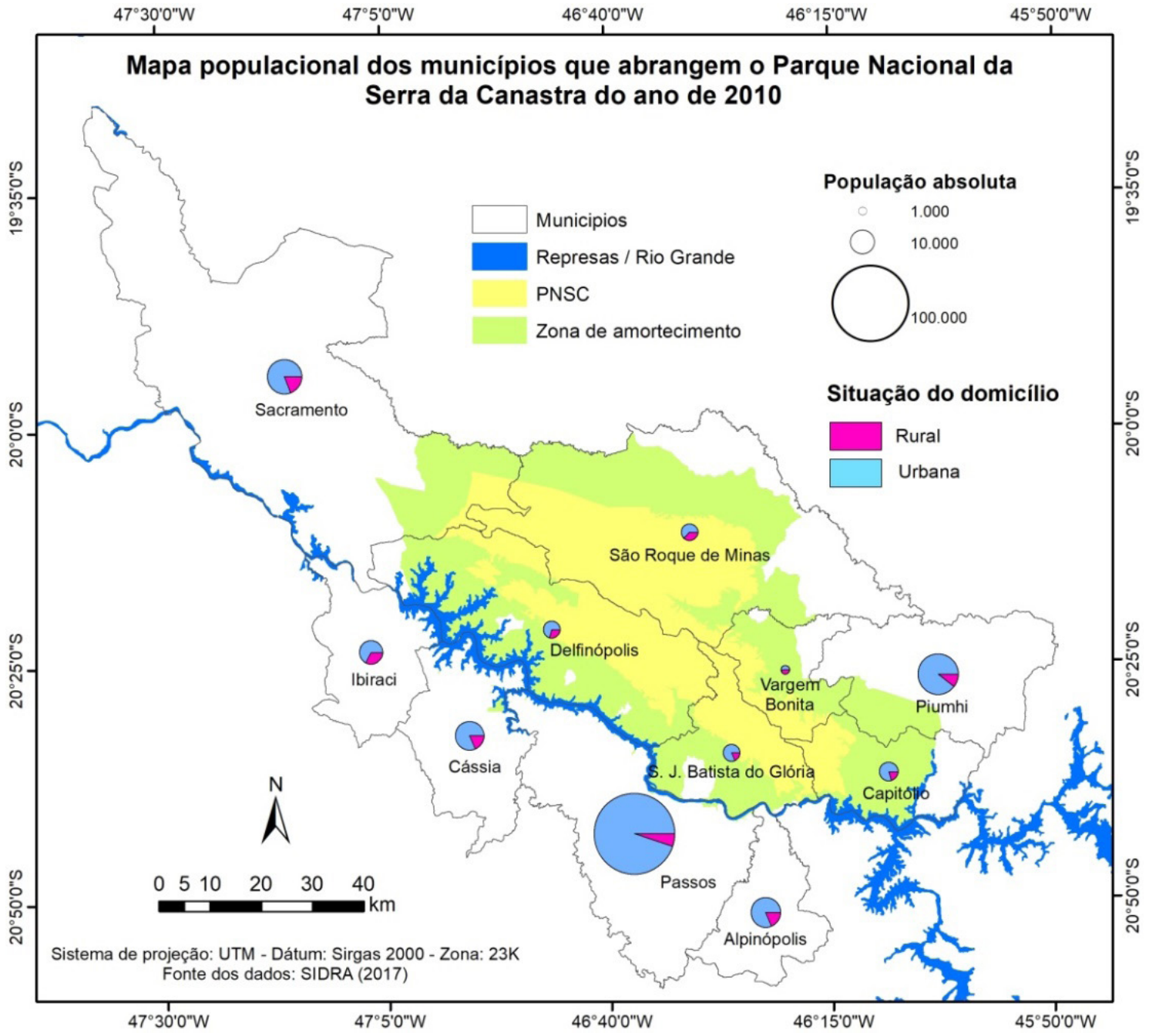

Fonte dos dados: Censo Demográfico de 2010, adquiridos pelo SIDRA (2017).

O mapa de densidade populacional (Figura 14) revela que grande parte da ZA apresenta maior concentração populacional, entre 1 e 14 habitantes por $\mathrm{km}^{2}$. Percebe-se que, nas proximidades com o rio Grande, as quadrículas com presença populacional são espacialmente mais concentradas, o que é menos comum em qualquer outra área. Isto ocorre porque, além da concentração de atividades agrícolas, as represas formadas pelas hidrelétricas ali instaladas são atrativos populacionais. As quadrículas com as maiores concentrações de população ocorrem no setor sudeste da área de estudo, em trechos da ZA que estão nos municípios de Capitólio e Piumhi, e que podem chegar a até 221 habitantes por $\mathrm{km}^{2}$. 
Figura 14: Mapa de densidade populacional, por quadrículas regulares, do PNSC.

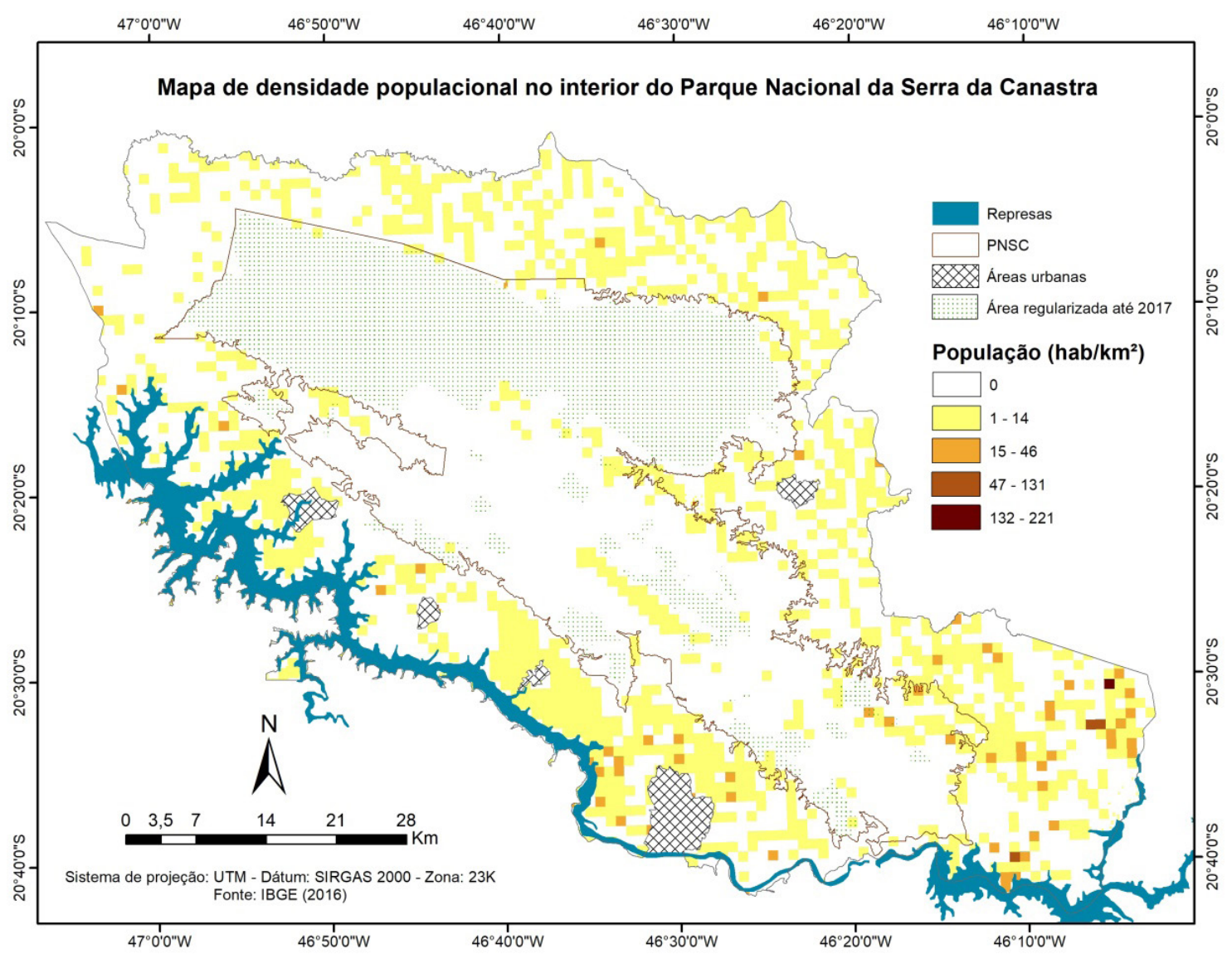

Fonte: Adaptado de IBGE (2016).

É possível constatar que, dentro do perímetro do PNSC, há presença populacional em locais específicos. No Chapadão da Canastra, área que foi regularizada no processo de criação deste parque, não há população residente. Os topos do Chapadão da Babilônia e suas áreas regularizadas também são desprovidos de população, mas as depressões intermontanas concentram propriedades rurais, áreas de camping, pousadas e hotéis-fazenda.

\section{Caracterização econômica dos municípios que compõem o PNSC}

Desde o século XIX, já se documentava a importância da pecuária e da agricultura, na serra da Canastra. Neste período, o naturalista Auguste de Saint-Hilaire registrou a existência de cabeças de gado e o plantio de milho e de outros alimentos (SAINT-HILAIRE, 1937). Apesar da redução de terras destinadas à agricultura e à pecuária, devido à implantação do PNSC, assim como o êxodo rural causado pelas transformações nesta região, as atividades

D

D

D Revista da Associação Nacional de Pós-graduação e Pesquisa em Geografia (Anpege).

D $D$

p.71-112, V.15, n.27, mai./ago. 2019. 
rurais ali aumentaram significativamente, nas últimas décadas. O surgimento de cooperativas de crédito agrícola e de produtores rurais possibilitou o crescimento desse setor (BIZERRIL et al., 2008).

A produção do queijo canastra, assim como de outros laticínios, é também uma importante atividade econômica típica dessa região. O início da produção deste tipo de queijo se deu no século XVIII, e, ainda nos dias atuais, as práticas tradicionais de sua produção continuam vivas (BIZERRIL et al., 2008), mas o crescimento da procura e a expansão do mercado consumidor levaram a transformações nesta produção (MMA, IBAMA, 2005).

O garimpo também levou ao desenvolvimento econômico dos municípios dessa região, atraindo aventureiros e viajantes de vários lugares do Brasil para explorar diamantes ali (BIZERRIL et al., 2008). Há também a exploração de quartzito (popularmente chamado de pedra São Thomé), nos municípios de São João Batista do Glória e Capitólio, dentro e fora da área do PNSC (MMA, IBAMA, 2005).

O turismo rural é uma atividade econômica tardia, que ganhou força no fim dos anos 1990. No início de 2000, houve o incentivo da mídia a este turismo, devido aos 500 anos da descoberta da nascente do rio São Francisco. Naquele momento, aumentou o número de pessoas interessadas nessa atividade e se investiu na ampliação da estrutura turística. Existem, na região, ao menos, 50 cachoeiras (BIZERRIL et al., 2008).

No que concerne ao Produto Interno Bruno (PIB) per capita dos municípios do PNSC, de maneira geral, não são observados valores elevados. Grande parte destes municípios apresenta o PIB inferior a outros municípios do estado de Minas Gerais, sendo que apenas os municípios de Ibiraci e Sacramento apresentam valores PIB per capita acima do estadual (Figura 15). 
Figura 15: PIB per capita de Minas Gerais e dos municípios que compõem o PNSC.

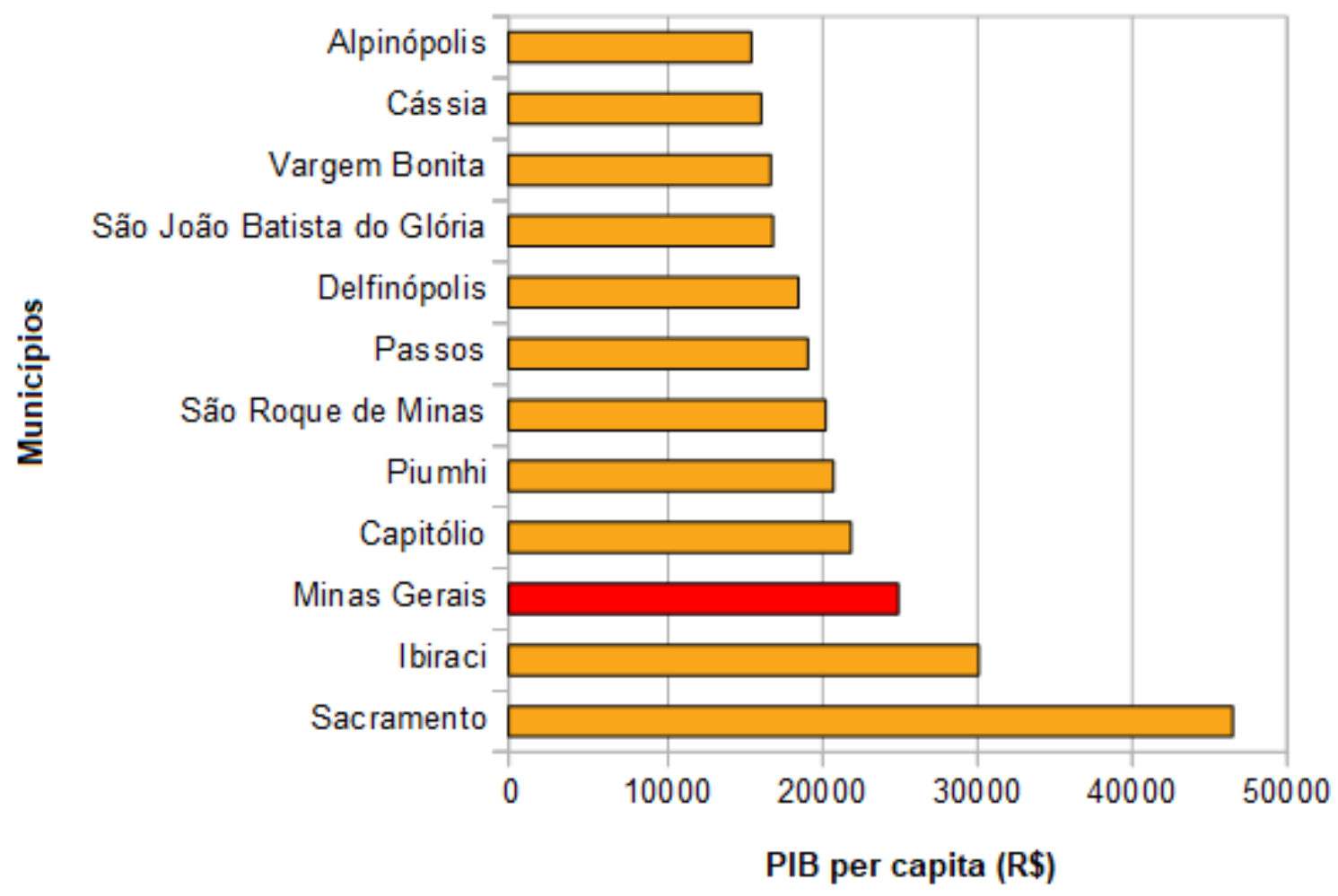

Fonte: IBGE (2017).

No que se refere ao percentual de participação dos setores na economia dos municípios, os que abrangem a área do PNSC destacam uma participação expressiva do setor primário ou terciário em sua economia (Figura 16). Por outro lado, a maioria dos municípios que formam a ZA apresenta maior participação do setor terciário em sua economia. Ibiraci é o único município da ZA em que o setor primário é predominante, mas é o que apresenta maior representatividade do setor secundário, o que faz com que o seu PIB per capita esteja acima da média do estado.

D

D

D D Revista da Associação Nacional de Pós-graduação e Pesquisa em Geografia (Anpege).

$D^{D}$

p.71-112, V.15, n.27, mai./ago. 2019. 
Figura 16: Mapa de participação dos setores na economia dos municípios que abrangem o PNSC.

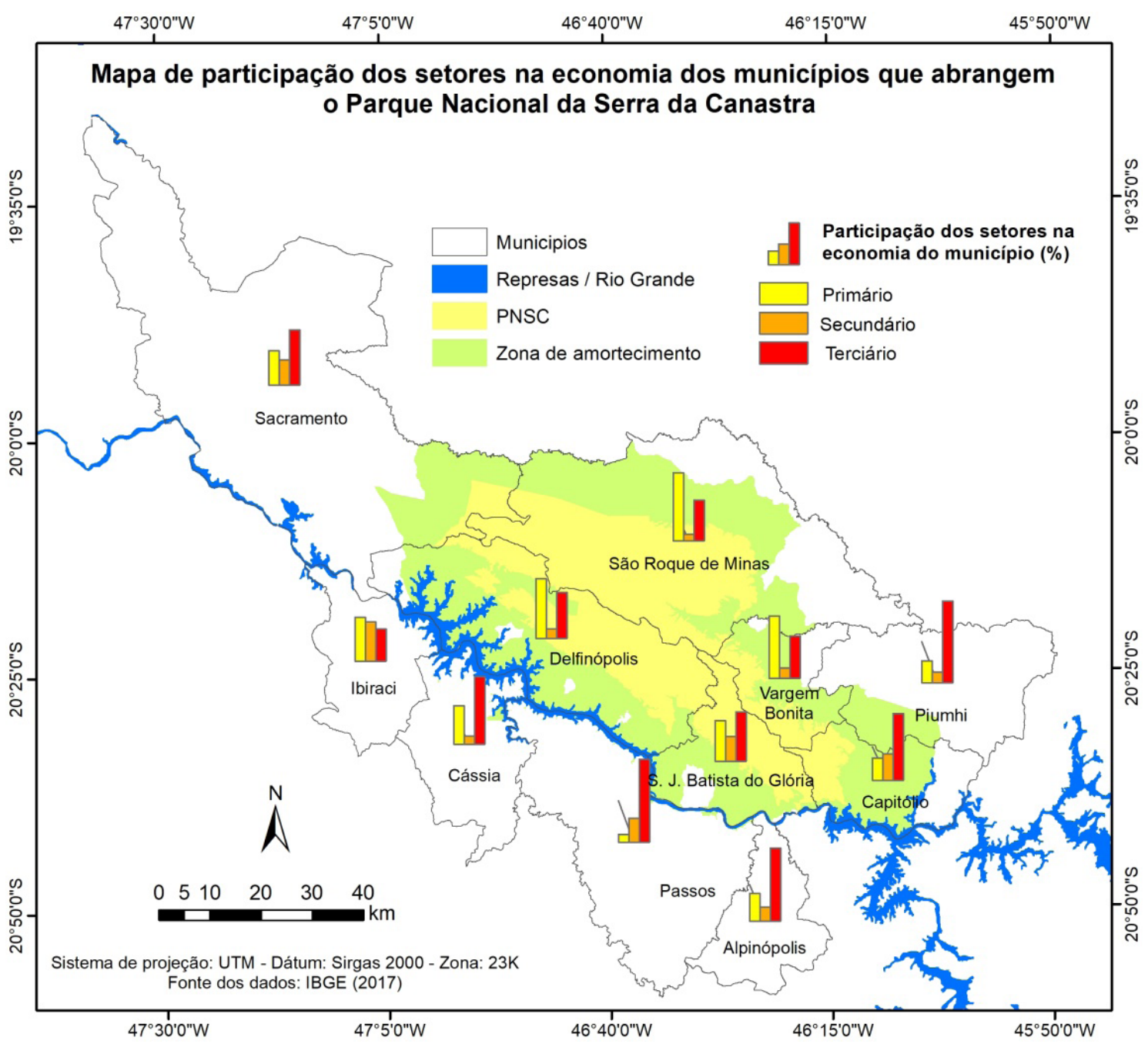

Fonte dos dados: IBGE (2017)

As atividades relacionadas ao setor primário nos municípios estão relacionadas, basicamente, à produção agrícola e pecuária. Os principais cultivos agrícolas dessa região são café, cana-de-açúcar, feijão, milho e soja. Além do mais, observam-se áreas de silvicultura de eucalipto. A criação de gado é a principal atividade pecuária, mas há também a criação de suínos e de aviários (Tabela 3). 
Tabela 3: Principais atividades ligadas ao setor primário, nos municípios que compõem o PNSC.

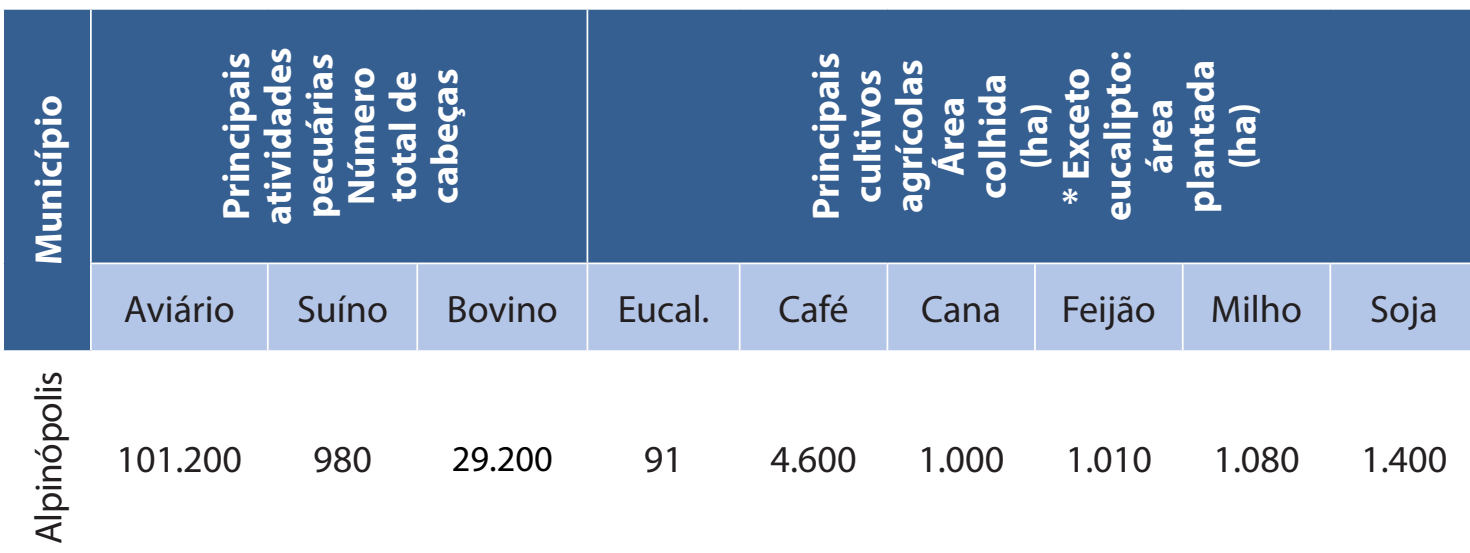

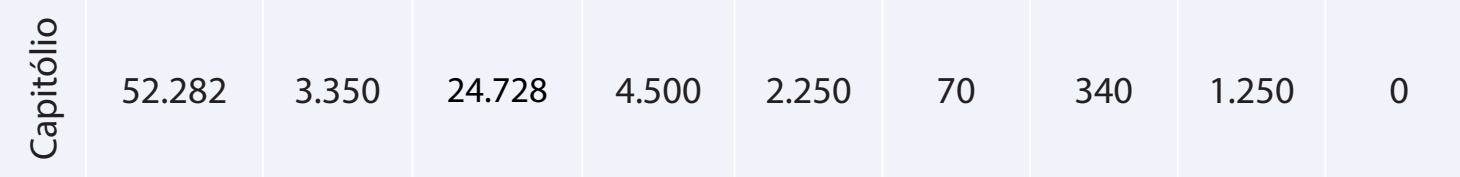

\begin{tabular}{|c|c|c|c|c|c|c|c|}
\hline 273.000 & 1.420 & 55.430 & 2.020 & 5.100 & 749 & 180 & 2.900 \\
\hline
\end{tabular}

\begin{tabular}{|c|c|c|c|c|c|c|c|c|c|}
\hline 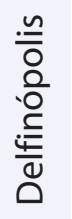 & 39.500 & 2.430 & 40.500 & 360 & 170 & 2.900 & 180 & 3.700 & 8.800 \\
\hline $\begin{array}{l}\bar{ত} \\
. \overline{0} \\
\text { e }\end{array}$ & 30.250 & 1.810 & 22.150 & 7.200 & 12.730 & 0 & 20 & 900 & 1.200 \\
\hline 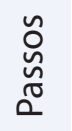 & 150.000 & 32.000 & 136.500 & 773 & 2.800 & 11.600 & 2.600 & 6.500 & 6.000 \\
\hline$\frac{\bar{c}}{\underline{\varepsilon}}$ & 330.000 & 2.600 & 56.353 & 8.700 & 11.780 & 80 & 1.700 & 8.650 & 1.300 \\
\hline 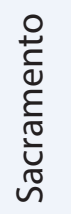 & 142.960 & 1.720 & 140.898 & 17.000 & 2.000 & 16.260 & 3.500 & 21.000 & 31.000 \\
\hline
\end{tabular}

D

D D Revista da Associação Nacional de Pós-graduação e Pesquisa em Geografia (Anpege).

D D

p.71-112, V.15, n.27, mai./ago. 2019. 


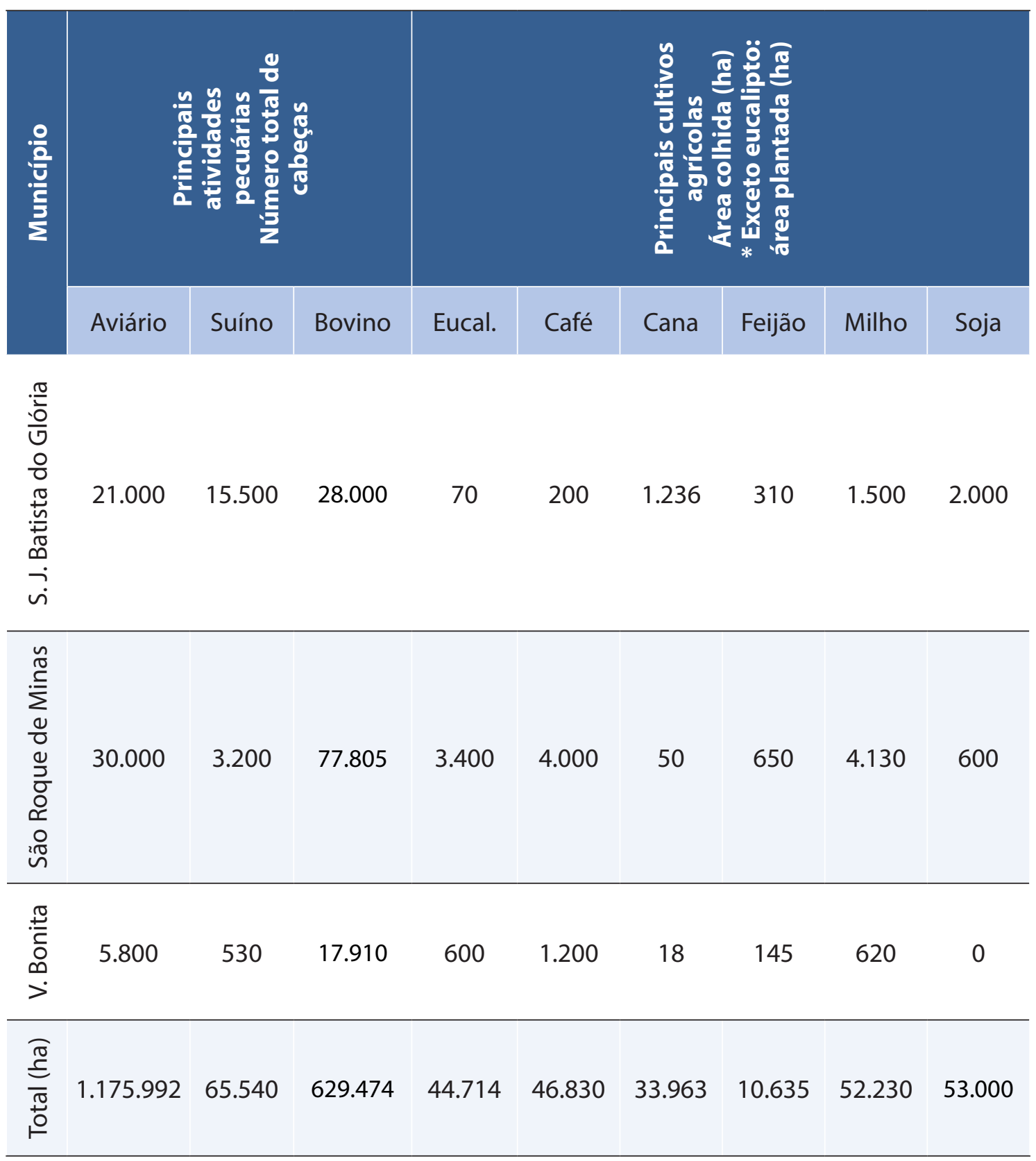

Fonte dos dados: Pesquisa da Pecuária Municipal de 2016 e Produção Agrícola Municipal de 2016, adquiridos pelo SIDRA (2017).

As propriedades destinadas às atividades primárias podem ser classificadas quanto à sua estrutura fundiária (Figura 17). Entre os municípios da ZA, Ibiraci, Cássia e Alpinópolis possuem a maioria das propriedades menores que 20 ha, consideradas minifúndios. Alpinópolis destaca a produção de café, cana, feijão, milho e soja; em Cássia, há o predomínio de café, milho e eucalipto, além da criação de aviários; em Ibiraci, há café e eucalipto. No caso de Passos e Piumhi, as propriedades são, em sua maioria, classificadas como pequenas, 
entre 20 e 100 ha. Em Passos, há destaque para a produção de cana, milho e soja e para a criação de bovinos, equinos e aviários; em Piumhi, evidenciam-se o café, o milho e o eucalipto, além de aviários.

Com exceção de Capitólio, onde predominam os minifúndios, em todos os municípios que formam o PNSC, prevalecem as pequenas propriedades. Sacramento tem a soja como o principal cultivo agrícola, mas também se destacam a cana, o milho e o eucalipto; em São Roque de Minas, Vargem Bonita e Capitólio, municípios ao norte do PNSC, as culturas de café, milho e eucalipto são predominantes; em Delfinópolis e São João Batista do Glória, ao sul do PNSC, a soja, o milho e a cana são os principais cultivos. Além da produção agrícola, há ênfase na criação de bovinos e aviários, em Sacramento, de bovinos, em São Roque de Minas, e de equinos, em São João Batista do Glória.

As médias propriedades, cujas áreas variam entre 100 e 500 ha, aparecem, com maior frequência, em Sacramento, Delfinópolis, São Roque de Minas e Vargem Bonita. As grandes propriedades, maiores que 500 ha, têm pequeno destaque, porém, Sacramento, Delfinópolis, São Roque de Minas e Vargem Bonita apresentam valores superiores aos demais municípios. Comprova-se, então, que há uma tendência dos municípios que abrangem o PNSC de apresentarem propriedades com áreas superiores.

Os dados do Cadastro Central de Empresas permitiram investigar quais são as principais atividades ligadas ao setor secundário, na região do PNSC. As indústrias extrativistas, as indústrias de transformação e a construção civil têm destaque, e o número de empresas por atividade está relacionado na Tabela 4. 
Figura 17: Estrutura fundiária dos municípios que abrangem o PNSC, no ano de 2006.

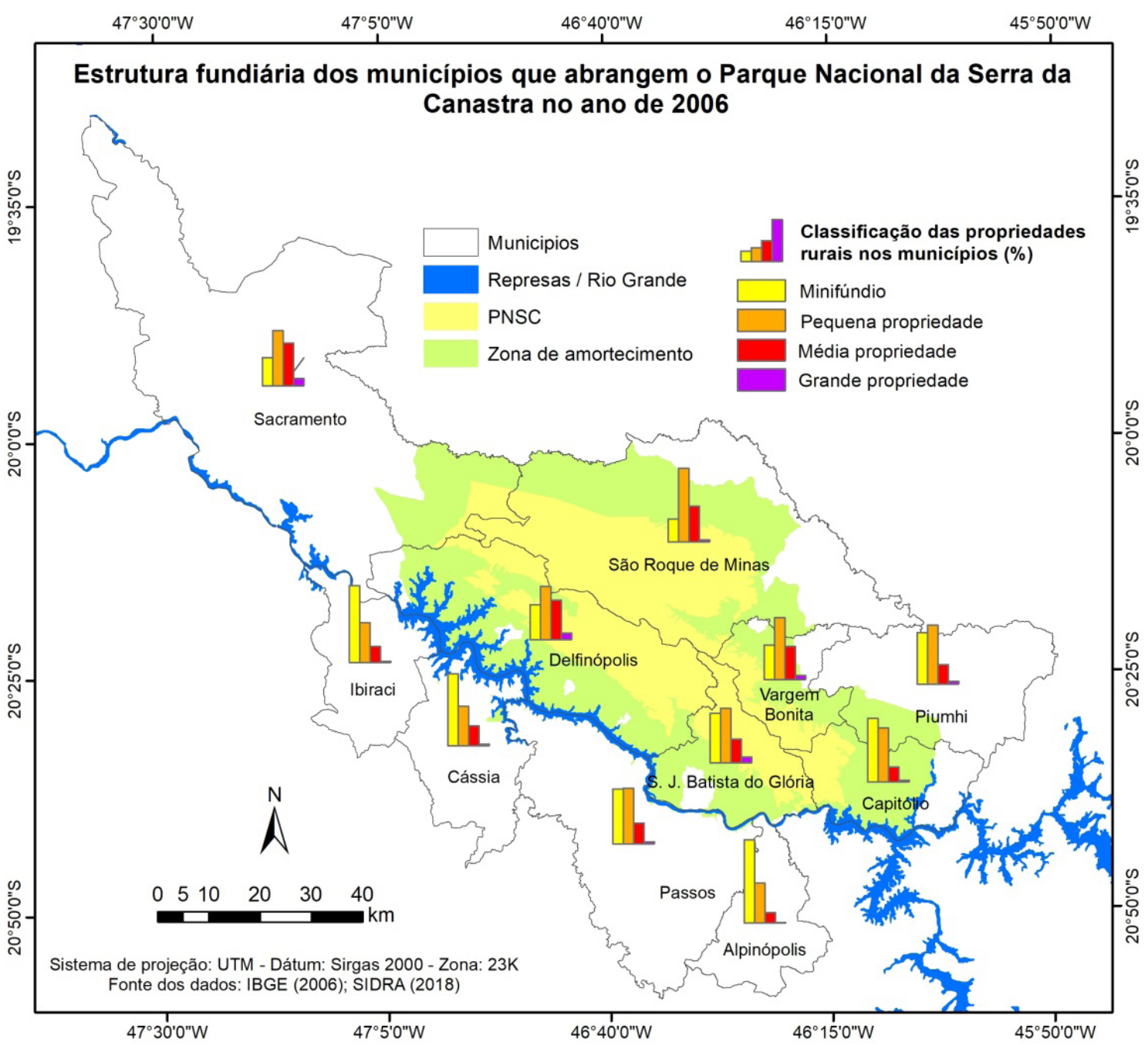

Fonte dos dados: Censo Agropecuário de 2006, adquiridos pelo SIDRA (2017).

Tabela 4: Principais atividades ligadas ao setor secundário, nos municípios que compõem o PNSC (número de empresas).

\begin{tabular}{|c|c|c|c|}
\hline Município & $\begin{array}{l}\text { Indústrias } \\
\text { extrativistas }\end{array}$ & $\begin{array}{l}\text { Indústrias de } \\
\text { transformação }\end{array}$ & Construção civil \\
\hline Alpinópolis & 8 & 47 & 28 \\
\hline Capitólio & 6 & 29 & 23 \\
\hline Cássia & 4 & 82 & 11 \\
\hline Delfinópolis & 0 & 5 & 9 \\
\hline Ibiraci & 3 & 13 & 5 \\
\hline Passos & 6 & 398 & 108 \\
\hline
\end{tabular}




\begin{tabular}{c|c|c|c}
\hline Município & $\begin{array}{c}\text { Indústrias } \\
\text { extrativistas }\end{array}$ & $\begin{array}{c}\text { Indústrias de } \\
\text { transformação }\end{array}$ & Construção civil \\
\hline Piumhi & 0 & 119 & 33 \\
\hline Sacramento & 10 & 92 & 37 \\
\hline São João Batista do Glória & 0 & 11 & 7 \\
\hline São Roque de Minas & 1 & 17 & 1 \\
\hline Vargem Bonita & 2 & 7 & $\mathbf{2 6 3}$ \\
\hline Total & $\mathbf{4 0}$ & $\mathbf{8 2 0}$ & 1 \\
\hline
\end{tabular}

Fonte dos dados: Cadastro Central de Empresas de 2015, adquiridos pelo SIDRA (2017).

De maneira geral, os municípios que abrangem as áreas do PNSC têm baixo número de empresas. Destacam-se a produção de laticínios e de alimentos, a confecção de peças de vestuário e a fabricação de bebidas alcoólicas (SIDRA, 2017). O principal produto associado à região é o queijo canastra, mas são também fabricados outros produtos alimentícios, de forma artesanal, tais como pães de queijo, roscas, broas, biscoitos e bolos (BIZERRIL et al., 2008).

Por outro lado, os municípios que estão na ZA revelam maior número de empresas. Sobressaem os valores expressos no município de Passos, que também concentra o maior contingente populacional em relação ao restante, e suas maiores produções estão associadas a produtos alimentícios, laticínios e têxteis, à fabricação de artefatos de concreto e cimento, a produtos de metal e equipamentos de transporte (SIDRA, 2017).

Em relação ao setor terciário, há destaque para as atividades comerciais (Tabela 5). Os municípios associados diretamente ao PNSC (exceto Sacramento) exibem valores modestos nas demais atividades, pois, em muitos deles, a economia está relacionada essencialmente ao setor primário. O turismo ligado à região do parque proporciona destaque no setor de alojamentos, em Capitólio, Delfinópolis, Piumhi, São João Batista do Glória e São Roque de Minas. As atividades imobiliárias, em Capitólio, também são representativas, devido ao forte turismo de luxo associado a este município.

D 
Tabela 5: Principais atividades ligadas ao setor terciário, nos municípios que compõem o PNSC (número de empresas).

\begin{tabular}{|c|c|c|c|c|c|c|}
\hline Município & 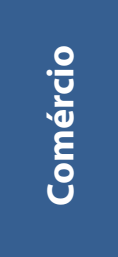 & 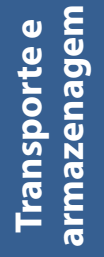 & 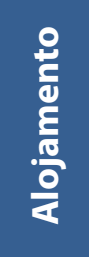 & 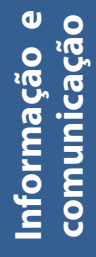 & 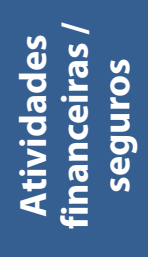 & 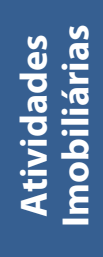 \\
\hline Alpinópolis & 178 & 37 & 18 & 7 & 2 & 6 \\
\hline Capitólio & 128 & 5 & 33 & 5 & 8 & 24 \\
\hline Cássia & 194 & 46 & 28 & 6 & 3 & 3 \\
\hline Delfinópolis & 67 & 10 & 22 & 1 & 4 & 4 \\
\hline Ibiraci & 130 & 12 & 18 & 3 & 0 & 1 \\
\hline Passos & 1.426 & 193 & 176 & 54 & 40 & 39 \\
\hline Piumhi & 569 & 47 & 50 & 14 & 11 & 22 \\
\hline Sacramento & 348 & 76 & 76 & 13 & 5 & 8 \\
\hline S. J. Batista do Glória & 68 & 11 & 21 & 2 & 1 & 0 \\
\hline São R. de Minas & 69 & 6 & 13 & 1 & 2 & 1 \\
\hline Vargem Bonita & 15 & 0 & 3 & 0 & 0 & 0 \\
\hline Total & 3.192 & 443 & 458 & 106 & 76 & 108 \\
\hline
\end{tabular}

Fonte dos dados: Cadastro Central de Empresas de 2015, adquiridos pelo SIDRA (2017).

\section{Considerações finais}

A região da serra da Canastra está inserida no domínio morfoclimático do cerrado. A área do Parque Nacional da Serra da Canastra engloba duas unidades geomorfológicas: a serra da Canastra (que estrutura os chapadões quartzíticos da Canastra e da Babilônia) e Patamares da Canastra (que formam áreas rebaixadas), com solos, na maioria das vezes, pouco profundos e com baixa fertilidade natural. Os chapadões são formados basicamente por fitofisionomias campestres, enquanto a zona de amortecimento é formada por agricultura, pastagens e fragmentos de mata. O interior do parque possui extensa rede de drenagem e atua como um divisor de águas das bacias hidrográficas do rio Grande, do rio Paranaíba e do rio São Francisco, além de proteger as nascentes dos rios São Francisco e Araguari. 
Os municípios que abrangem o PNSC apresentam contingente populacional que varia entre 2.163 (Sacramento) e 106.290 habitantes (Passos). Sua população se concentra, principalmente, na zona de amortecimento, mas também nas depressões intermontanas, localizadas nas zonas não regularizadas do parque. Grande parte desses municípios apresenta PIB per capita abaixo do estado de Minas Gerais, e seus municípios destacam a participação expressiva dos setores primário ou terciário na economia. As atividades relativas ao setor primário estão relacionadas, basicamente, às produções agrícola e pecuária; no setor secundário, se destacam as indústrias extrativistas, as indústrias de transformação e a construção civil; e, no setor terciário, sobressaem as atividades comerciais.

O PNSC abrange uma área de 197.787, e o seu processo de regularização fundiária tem sido, ao longo do tempo, associado a muitos conflitos territoriais. Mais de quarenta anos após a sua criação, somente o Chapadão da Canastra e pequenos fragmentos do Chapadão da Babilônia são de posse da União, sendo que a área regularizada atual é de 86.203 ha. A não regularização do Chapadão da Babilônia tem permitido o desenvolvimento de diversas atividades conflitantes, portanto, a sua regularização fundiária é essencial para que a conservação ocorra de forma mais efetiva.

\section{Referências bibliográficas}

1. AB'SABER, A. N. Os domínios da natureza no Brasil: potencialidades paisagísticas. $7^{\mathrm{a}}$ ed. São Paulo: Ateliê Editorial, 2012, 158 p.

2. BARBOSA, C. Territórios de vida e trabalho dos pequenos produtores de queijo da serra da Canastra: um estudo sobre a relação entre a produção camponesa e espaços naturais protegidos nas nascentes do rio São Francisco, Minas Gerais. Dissertação (Mestrado em Geografia). Universidade Federal de Uberlândia, Uberlândia, 2007.

3. BASTOS, L. A.; FERREIRA, I. M. Composições fitofisionômicas do bioma cerrado: estudo sobre o subsistema de vereda. In: Espaço em Revista, v. 12, n. 1, p. 97-108, 2010.

4. BENITEZ. Províncias diamantíferas de Minas Gerais: uma proposta para a caracterização de populações de diamantes típicas como subsídio à certificação Kimberley. Tese (Doutorado em Geologia). Universidade Federal de Minas Gerais, Belo Horizonte, 2009.

5. BIZERRIL, M.; SOARES, C. C.; SANTOS, J. P. Um lugar chamado Canastra. Atibaia: Instituto Pró-Carnívoros, 2008, 81 p.

6. BIZZI, L. A.; SCHOBBENHAUS, C.; VIDOTTI, R. M.; GONÇALVES, J. H. (eds.). Geologia, tectônica e recursos minerais do Brasil: texto, mapas e SIG. Brasília: CPRM, Brasília, 2003.

D 
7. BRASIL. Decreto ${ }^{\circ} 70.355$, de 3 de abril de 1972. Cria o Parque Nacional da Serra da Canastra, no Estado de Minas Gerais, com os limites que especifica, e dá outras providências. Publicado no D.O.U. de 4 de abril de 1972.

8. CBHSF. Resumo executivo do Plano de Recursos Hídricos da Bacia Hidrográfica do rio São Francisco 2016-2025. Alagoas: CBHSF, 2016.

9. CBH ARAGUARI. Disponível em: <http://www.cbharaguari.org.br/>. Acesso em: 02 dez. 2017.

10. CBH GRANDE. Disponível em: <http://www.grande.cbh.gov.br/>. Acesso em: 02 dez. 2017.

11. CBH PARANAÍBA. Disponível em: <http://www.paranaiba.cbh.gov.br/> Acesso em: 02 dez. 2017.

12. CHAVES, M. L. S. C.; ANDRADE, K. W.; BENITEZ, L.; BRANDÃO, P. R. G. Província diamantífera da serra da Canastra e o Kimberlito Canastra-1: primeira fonte primária de diamantes economicamente viável do país. In: Geociências, v. 27, n. 3, p. 229-317, 2008.

13. CHAVES, M. L. S. C.; BENITEZ, L.; ANDRADE, K. W. Cachoeira Casca d’Anta, São Roque de Minas: berço do velho Chico, rio da integração nacional. In: WINGE, M.; SCHOBBENHAUS, C.; SOUZA, C. R. G.; FERNANDES, A. C. S.; BERBERT-BORN, M.; QUEIROZ, E. T. (edit.). Sítios geológicos e paleontológicos do Brasil. Brasília: CPRM, 2009.

14. CONGALTON, R. G.; GREEN, K. Assessing the accuracy of remotely sensed data: principles and practices. Boca Raton: CRC Press, 1999.

15. CONTI, J. B.; FURLAN, S. A. Geoecologia: o clima, os solos e a biota. In: ROSS, J. L. S. (org.). Geografia do Brasil, 6a ed., São Paulo: Edusp, 2011.

16. COUTINHO, L. M. O bioma do cerrado. In: KLEIN, A. L. (org.). Eugen Warming e o cerrado brasileiro: um século depois. São Paulo: UNESP, p. 77-92, 2002.

17. COUTO JUNIOR, A. F.; SOUZA, V. V.; CARVALHO JUNIOR, O. A.; MARTINS, E. S.; SANTANA, O. A.; FREITAS, L. F.; GOMES, R. A. T. Integração de parâmetros morfométricos e imagem ASTER para a delimitação das fitofisionomias da serra da Canastra, Parque Nacional da Serra da Canastra/MG. In: Revista Brasileira de Geomorfologia, v. 11, n. 1, p. 57-68, 2010.

18. CPRM. Downloads. Disponível em: <http://geosgb.cprm.gov.br/downloads/>. Acesso em: 15 nov. 2017.

19. CUNHA, S. B. Bacias hidrográficas. In: CUNHA, S. B.; GUERRA, A. J. T. (orgs.). Geomorfologia do Brasil, 8a ed. Rio de Janeiro: Bertrand do Brasil, 2012. 
20. FERREIRA, G. H. C. O Parque Nacional da Serra da Canastra/MG: algumas propostas, conflitos e incertezas territoriais. In: Revista Cerrados, v. 13, n. 1, p. 111-139, 2015.

21. GARÓFALO, D. F. T.; MESSIAS, C. G.; LIESENBERG, V.; BOLFE, E. L.; FERREIRA, M. C. Análise comparativa de classificadores digitais em imagens do Landsat-8 aplicados ao mapeamento temático. In: Pesquisa Agropecuária Brasileira, v. 50, n. 7 , p. 593-604, 2015.

22. HAMEDIANFAR, A.; SHAFARI, H. Z. M. Development of fuzzy rule-based parameters for urban object-oriented classification using very high resolution imagery. In: Geocarto International, v. 29, n. 3, 268-292, 2014.

23. IBGE. Manual técnico de geomorfologia. $2^{\text {a }}$ ed. Rio de Janeiro: IBGE, 2009.

24. Censo demográfico 2010: grade estatística. Disponível em: <http:// mapasinterativos.ibge.gov.br/grade/default.html>. Acesso em: 10 dez. 2016.

25. IBGE cidades. Disponível em: <https://cidades.ibge.gov.br/>. Acesso em: 08 jun. 2017.

26. INCRA. Classificação dos imóveis rurais. Disponível em: <http://www.incra.gov.br/ tamanho-propriedades-rurais $>$. Acesso em: 07 out. 2017.

27. IPEA. Aproveitamento atual e potencial dos cerrados. Vol. 1: base física e potencial da região. Brasília: IPEA, 1973.

28. MELLES, C.; CUNHA, O.; LARA, M. C.; THADEU, G.; GUERRA, R. Projeto de Lei $\mathrm{n}^{\circ}$ 1448, de 28 de junho de 2007. Altera os limites do Parque Nacional da Serra da Canastra, que passa a compor o mosaico de unidades de conservação da serra da Canastra, nos termos do art. 26 da Lei nº 9.985, de 18 de julho de 2000. Brasília, 2007.

29. Projeto de Lei no 6.905, de 2010. Cria o

Monumento Natural do Rio Samburá, que passa a compor o mosaico de unidades de conservação da Serra da Canastra, nos termos do art. 26 da Lei n ${ }^{\circ}$ 9.985, de 18 de julho de 2000. Brasília, 2010.

30. MENEZES, M. D.; MESSIAS, C. G.; SILVA, S. H. G.; CURI, N. Relações entre ambientes de solos e fitofisionomias. In: CARVALHO, D. A. Cerrados do sul e sudoeste de Minas Gerais: flora e ambiente. Lavras: Editora UFLA, 2017.

31. MESSIAS, C. G. Mapeamento das áreas suscetíveis à fragilidade ambiental na alta bacia do Rio São Francisco, Parque Nacional da Serra da Canastra/MG. 2014. Dissertação (Mestrado em Geografia). Universidade Estadual de Campinas, Campinas, 2014.

D 
32. MMA; IBAMA. Plano de manejo: Parque Nacional da Serra da Canastra. Brasília: MMA, 2005.

33. MMA; IBAMA; PREFOGO; PNSC. Plano de prevenção aos incêndios florestais: Parque Nacional da Serra da Canastra. São Roque de Minas: PNSC, 2005.

34. MMA; ICMBIO; PNSC. O Parque Nacional da Serra da Canastra: breves considerações históricas, logísticas e gerenciais. Processo 02070.000978/2018-19/SEI 2668224. São Roque de Minas: SEI, 2018.

35. NOVAIS, G. T. Caracterização climática da mesorregião do Triângulo Mineiro/ Alto Paranaíba e da serra da Canastra (MG). Dissertação (Mestrado em Geografia). Universidade Federal de Uberlândia, Uberlândia, 2011.

36. OTUKEI, J. R.; BLASCHKE, T. Land cover change assessment using decision trees, support vector machines and maximum likelihood classification algorithms. In: International Journal of Applied Earth Observation and Geoinformation, v. 125, p. 527531, 2010.

37. PIRES, F. R. M. Arcabouço geológico. In: CUNHA, S. B.; GUERRA, A. J. T. (orgs). Geomorfologia do Brasil. Rio de Janeiro: Bertrand do Brasil, 2012.

38. RADAMBRASIL. Levantamento de recursos naturais: folhas SF 24-25 - Rio de Janeiro/ Vitória, v. 32. Rio de Janeiro: Divisão de Publicação, 1983, 775 p.

39. RIBEIRO, J. F.; SANO, S. M.; MACÊDO, J.; SILVA, J. A. Os principais tipos de fitofisionomias da região do cerrado. In: Boletim de Pesquisa, n. 1, Planaltina: Embrapa, 1983.

40. .; WALTER, B. M. T. Fitofisionomias do bioma cerrado. In: SANO, S. M.; ALMEIDA, S. P. (eds.). Cerrado: ambiente e flora. Brasília: Embrapa Cerrados, 1998.

41. ROSS, J. L. S. Relevo brasileiro: uma nova proposta de classificação. In: Revista do Departamento de Geografia, n. 4, 1985.

42. SAINT-HILAIRE, Auguste de. Viagem às nascentes do rio S. Francisco e pela província de Goyas. São Paulo: Companhia Editora Nacional, 1937.

43. SANTANA, A. S.; GERALDINE, C.; IMAÑA-ENCINAS, J. Contribuição da vegetação rasteira na evapotranspiração total em diferentes ecossistemas do bioma Cerrado, Distrito Federal. In: Ciência Florestal, v. 20, n. 2, p. 269-281, 2010.

44. SCARLATO, F. C. População e urbanização brasileira. In: ROSS, J. L. S. Geografia do Brasil. São Paulo: Edusp, 2011. 
45. SIDRA. Disponível em: <http://www2.sidra.ibge.gov.br/>. Acesso em: 22 dez. 2017.

46. TANNUS, J. L. S.; ASSIS, M. A. Composição de espécies vasculares de campo sujo e campo úmido em área de cerrado, Itirapina/SP, Brasil. In: Revista Brasil. Bot., v. 27, n. 3, p. 489-506, 2004.

47. UFV; CETEC; UFLA; FEAM. Mapa de solos do estado de Minas Gerais: legenda expandida. Belo Horizonte: FEAM, 2010, 49 p.

48. USGS. Earth explorer. Disponível em: <https://earthexplorer.usgs.gov/>. Acesso em: 02 out. 2018.

49. VASCONCELOS, V.; CARVALHO JUNIOR, O. A.; MARTINS, E. S.; COUTO JUNIOR, A. F.; GOMES, R. A. T. Sistema de classificação geomorfométrica baseada em uma arquitetura sequencial em duas etapas: árvore de decisão e classificador espectral, no Parque Nacional da Serra da Canastra. In: Revista Brasileira de Geomorfologia, v. 13, n. 2, p.171-186, 2012.

50. ZHOU, Z.; HUANG, J.; WANG, J.; ZHANG, K.; KUANG, Z.; ZHONG, S.; SONG, X. Object-oriented classification of sugarcane using time-series middle-resolution remote sensing data based on AdaBoost. In: PLoS ONE, v. 10, n. 11, p. 1-16, 2015. 